Western University

Scholarship@Western

$9-19-2018$

Evolution of grain size distributions and bed mobility during hydrographs in gravel-bed braided rivers

\author{
Sarah Peirce \\ Peter Ashmore \\ pashmore@uwo.ca \\ Pauline Leduc
}

Follow this and additional works at: https://ir.lib.uwo.ca/geographypub

Part of the Geomorphology Commons, Physical and Environmental Geography Commons, and the Sedimentology Commons

Citation of this paper:

Peirce, Sarah; Ashmore, Peter; and Leduc, Pauline, "Evolution of grain size distributions and bed mobility during hydrographs in gravel-bed braided rivers" (2018). Geography Publications. 365.

https://ir.lib.uwo.ca/geographypub/365 


\section{Earth Surface Processes and Landforms}

\section{Evolution of Grain Size Distributions and Bed Mobility during Hydrographs in Gravel-Bed Braided Rivers}

\begin{tabular}{|r|l|}
\hline Journal: & Earth Surface Processes and Landforms \\
\hline Manuscript ID & ESP-17-0361.R2 \\
\hline Wiley - Manuscript type: & Research Article \\
\hline Complete List of Authors: & $\begin{array}{l}\text { Peirce, Sarah; The University of Western Ontario, Geography } \\
\text { Ashmore, Peter; University of Western Ontario, Geography } \\
\text { Leduc, Pauline; Western University, Department of Geography }\end{array}$ \\
\hline Keywords: & Braided river, Physical model, bed mobility, grain size, gravel-bed \\
\hline
\end{tabular}




\title{
1 Evolution of Grain Size Distributions and Bed Mobility during Hydrographs in Gravel-Bed 2 Braided Rivers
}

\author{
3 S. Peirce ${ }^{1}$, P. Ashmore ${ }^{1}$, and P. Leduc ${ }^{1}$ \\ $4 \quad$ 'University of Western Ontario, London, Ontario, Canada \\ $5 \quad$ Corresponding author: Sarah Peirce (speirce@uwo.ca)
}

7 Key Points:

8 The transition from partial to selective mobility in physical models of gravel-bed braiding

9 rivers corresponds to the lower threshold of substantial morphological change and

10 bedload transport and occurs at approximately $50 \%$ of peak channel-forming discharge,

11 or dimensionless stream power of 70 . The expansion of the morphological active depth

12 and morphological active width with increasing discharge is directly related to the

13 mobilization of the coarsest grain size fractions, indicating that bedload grain size

14 distributions, while tied to hydraulic forcing, are also related to braiding morphodynamics. 


\section{Abstract}

16 Evolution of bed material mobility and bedload grain size distributions under a range of

17 discharges is rarely observed in braiding in gravel-bed rivers. Yet, the changing of

18 bedload grain size distributions with discharge is expected to be different from laterally-

19 stable, threshold, channels on which most gravel bedload theory and observation are

20 based. Here, simultaneous observations of flow, bedload transport rate, and

21 morphological change were made in a physical model of a gravel-bed braided river to

22 document the evolution of grain size distributions and bed mobility over three

23 experimental event hydrographs. Bedload transport rate and grain size distributions were

24 measured from bedload samples collected in sediment baskets. Morphological change

25 was mapped with high-resolution ( $\sim 1 \mathrm{~mm}$ precision) digital elevation models generated

26 from close-range digital photogrammetry. Bedload transport rates were extremely low

27 below a discharge equivalent to $\sim 50 \%$ of the channel-forming discharge (dimensionless

28 stream power $\sim 70$ ). Fractional transport rates and plots of grain size distributions indicate

29 that the bed experienced partial mobility at low discharge when the coarsest grains on

30 the bed were immobile, weak selective mobility at higher discharge, and occasionally

31 near-equal mobility at peak channel-forming discharge. The transition to selective mobility

32 and increased bedload transport rates coincided with the lower threshold for

33 morphological change measured by the morphological active depth and active width.

34 Below this threshold discharge, active depths were of the order of $D_{90}$ and active widths

35 narrow ( $<3 \%$ of wetted width). Above this discharge, both increased so that at channel-

36 forming discharge, the active depth had a local maximum of 9D9o while active width was

37 up to $20 \%$ of wetted width. The modelled rivers approached equal mobility when rates of 
38 morphological change were greatest. Therefore, changes in the morphological active

39 layer with discharge is directly connected to the conditions bed mobility, and strongly

40 correlated with bedload transport rate.

\section{Introduction}

42 The relationships between bedload grain size distributions (GSD), bed mobility, and

43 channel morphology in gravel-bed rivers have important implications for the basic

44 understanding of river dynamics as well as many practical applications. For example, this

45 data can be used to estimate bedload sediment yield and channel stability, which in turn

46 are used to inform channel, reservoir, and infrastructure design (Powell et al., 2001b;

47 Ryan et al., 2002). In addition, GSD and bed mobility data are necessary for the effective

48 numerical modelling of sediment entrainment and channel morphodynamics (Powell et

49 al., 2001b; Wilcock and McArdell, 1997a; Williams et al., 2016a, 2016b) and can help

50 define the disturbance regimes and substrate quality of gravel-bed rivers for benthic

51 organisms and fish (Haschenburger and Wilcock, 2003; Wilcock and McArdell, 1997a).

52 Individual grain size fractions in gravel bed rivers are defined as fully mobilized when the

53 entire population of that grain size available for transport in the bed material is entrained

54 during a flow event, otherwise the fraction is only partially mobilized (Haschenburger and

55 Wilcock, 2003; Wilcock and McArdell, 1997b). With regards to the channel bed as a

56 whole, three main mobility states have been defined for gravel-bed rivers: partial mobility,

57 selective mobility, and equal mobility (Parker, 2008; Venditti et al., 2017). Partial mobility

58 occurs when the GSD of the bedload is finer than that of the bed because some coarse

59 fractions on the bed surface remain immobile, even during high flows. Selective mobility

60 occurs when all of the grain sizes on the surface are found in the bedload, but not in 
61 proportion to their availability on the bed, reflecting a mix of fully mobilized and partially

62 mobilized grain size fractions. Finally, equal mobility occurs when the GSD of the bedload

63 and bed material are identical (i.e., all grain size fractions are fully mobilized in proportion

64 to their availability).

65 While many studies have investigated changes in grain size and bed mobility for single-

66 thread gravel-bed rivers or in narrow, straight-walled flumes, there is comparatively little

67 research on these processes in braiding rivers (Ashworth et al., 1992; Ashworth and

68 Ferguson, 1986, 1989; Kociuba and Janicki, 2015; Mao and Surian, 2010). Defined by

69 their multiple anabranch channels and ephemeral bars, braided rivers have a complex

70 morphology producing spatially and temporally variable bedload transport rates

71 commonly observed in the field (Ashworth and Ferguson, 1986; Mao and Surian, 2010;

72 Powell and Ashworth, 1995; Williams et al., 2015b) and in physical models (Ashmore,

73 1988; Ashmore and Church, 1998; Hoey, 1992; Hoey and Sutherland, 1991). While there

74 has been some success characterizing bedload transport functions at the reach scale

75 using temporal averages (Ashmore, 1988; Bertoldi et al., 2009; Williams et al., 2016a),

76 the complex morphology and hydraulics as well as rapid morphological change makes

77 bedload transport rates and bed material mobility in braided rivers inherently difficult to

78 measure directly, or to predict using classic hydraulically-driven bedload functions

79 (Bertoldi et al., 2009; Davies, 1987; Kociuba and Janicki, 2015; Mao and Surian, 2010;

80 Powell and Ashworth, 1995; Recking et al., 2016).

81 Though not thoroughly investigated in the past, bedload transport and mobility of bed

82 material particle size fractions over a range of discharges in braided rivers may behave

83 differently than laterally stable single-threaded channels for several reasons. First, 
84 braided rivers are often characterized by high sediment supply relative to bedload

85 transport capacity (Ferguson, 1987; Mueller and Pitlick, 2013, 2014). High rates of lateral

86 migration (i.e., bank and bar erosion) and an extensive morphological active layer

87 (Ashmore et al., 2018) provide locally high rates of sediment input to bedload transport

88 (Wheaton et al., 2013; Williams et al., 2015b) at the channel scale in combination with

89 high rates of sediment supply provided at the watershed scale (Guerit et al., 2014; Mueller

90 and Pitlick, 2014; Piegay et al., 2006). As a consequence, braided rivers often lack strong

91 surface armour (Bunte and Abt, 2001; Gardner and Ashmore, 2011a; Gardner et al.,

92 2017; Guerit et al., 2014; Leduc et al., 2015; Mueller and Pitlick, 2013, 2014) and

93 differences in surface and subsurface GSDs may be small (Carson and Griffiths, 1987;

94 Laronne et al., 1994; Laronne and Reid, 1993; Lisle, 1995; Lisle et al., 2000; Mueller and

95 Pitlick, 2013) unlike typical stable, single-thread gravel-bed rivers that often have a

96 distinct coarse surface layer relative to the subsurface sediment. At the same time,

97 braided rivers exhibit a wide range of bed material particle sizes available at the bed

98 surface due to processes like strong lateral sorting effects around bars (Ashworth and

99 Ferguson, 1986; Bluck, 1979; Leduc et al., 2015; Smith, 1974). Furthermore, recent

100 research has shown no significant vertical sorting within braided river deposits and that

101 the morphological active depth (i.e. vertical depth of morphological change and bed

102 material turnover) extends to several multiples of the surface D90, making it possible to

103 mobilize large portions of the subsurface material during active braiding (Ashmore et al.,

104 2018; Gardner and Ashmore, 2011b; Gardner et al., 2017; Leduc et al., 2015). Second,

105 and following from this, braided rivers actively rework large areas of the bed over short

106 time periods (e.g., single flow events) (Ashmore, 2013; Ashmore et al., 2018; Leduc et 
107 al., 2015; Wheaton et al., 2013; Williams et al., 2015a, 2016a, 2016b). This occurs in part 108 because the area of the bed that is wetted and experiencing active bedload transport (i.e. 109 the morphological active width) increases rapidly with discharge in braided rivers 110 (Ashmore et al., 2011; Lugo et al., 2015; Peirce et al., 2018). The lateral adjustment of 111 the morphological active width with discharge is a significant component of bed material 112 transport in braiding rivers (Bertoldi et al., 2009; Peirce et al., 2018; Williams et al., 2015b) 113 that aids in the accessibility of a wide range of bed material particle sizes, both laterally 114 and from the subsurface. These processes differ from more-stable, single-threaded 115 channels, which can have immobile areas of the bed that persist for years 116 (Haschenburger and Wilcock, 2003) and in which bedload mechanics are dominated by 117 particle exchange at the bed with limited active layer depth (Church and Haschenburger, 118 2017). Overall, these differences between braiding and stable single channels may have 119 important implications for predicting fractional and total transport rates and bed mobility.

120 While most gravel-bed rivers are restricted to low transport rates and partial mobility due 121 to surface armour (Church and Hassan, 2002; Venditti et al., 2017), braided rivers may 122 be able to mobilize large areas and volumes of bed material as well as wide range of 123 grain sizes (Ashworth and Ferguson, 1986, 1989; Mueller and Pitlick, 2014; Powell et al., 124 2001a) and consequently may show a different response to discharge than stable, near125 threshold channels (see Church, 2006). However, there are very few data available for 126 bedload particle mobility in gravel braided rivers. Ashworth and Ferguson (1986; 1989) 127 observed that at the highest flows in a pro-glacial braided outwash, the particle size 128 distribution of the bedload began to approach that of the braidplain deposits as a whole, 129 although never reaching true equal mobility, and that mobility was greater in this actively 
130 braiding river than in two other more-stable rivers (Ashworth and Ferguson, 1989). Lisle 131 (1995) found that, for a range of gravel bed river types, those with high average active 132 layer depths (e.g., 4-12 $\times D_{84}$ ), in which large areas of the streambed are mobilized during 133 bedload transport events, had the greatest tendency to approach conditions of equal 134 mobility and a braiding morphology.

135 Overall, it is expected that gravel-bed braided rivers may evolve towards full mobilization 136 of coarse grains and equal mobility of the bed differently and at lower discharges (relative 137 to 'bankfull') than more-stable, single-thread gravel-bed rivers. This evolution is likely to 138 be associated with periods of rapid morphological change, and an extensive 139 morphological active layer, both laterally and vertically (Ashmore et al., 2018). Yet, due 140 to the demand for simultaneous measurements of bedload transport flux and 141 morphological change, which would be practically impossible to collect in the field, these 142 relationships between bedload and morphological change have not been systematically 143 investigated in gravel-bed braided rivers. Here, we used a small-scale physical model of 144 a gravel-bed braided river to obtain measurements of bedload transport rates, bedload 145 grain size distributions, and morphological change over three experimental hydrographs 146 reproducing diurnal meltwater discharge variation in a pro-glacial braided river. The use 147 of a physical model allowed for bedload to be collected in traps at the outlet of the model 148 while concurrent measurements of morphological change were determined via 149 differencing of high-resolution and high-frequency digital elevation models (DEMs) 150 (Brasington et al., 2000; Kasprak et al., 2015; Morgan et al., 2016). Therefore, we can 151 quantitatively link changes in bedload transport and GSDs with changes in discharge, as 152 well as the morphological active depth and the morphological active width in a braided 
153 river. This makes it possible to investigate bed material mobility as a component of the

154 intrinsically morphological process of bedload transport in braided rivers (Ashmore et al.,

155 2011, 2018; Ashmore and Church, 1998; Bertoldi et al., 2009) and to characterize an

156 aspect of gravel-bed braiding river dynamics and bedload transport in a manner not 157 previously accomplished.

\section{Methods}

159 Physical Model

160 Data were gathered from hydrograph experiments using a Froude-scaled physical model

161 of a gravel-bed braided river in a large river modelling flume $(18.3 \mathrm{~m} \times 3 \mathrm{~m})$ with adjustable

162 slope and discharge and recirculating water. Froude-scale modelling preserves dynamic 163 similarity so that fundamental force ratios, particularly non-dimensional bed shear stress,

164 are preserved and therefore both bedload transport and morphodynamic processes are 165 modelled (Ashmore, 1982; Young and Warburton, 1996). Reduced scale models of this 166 kind have been used extensively in research on gravel-bed braiding rivers (Ashmore, 167 1988, 1982; Warburton and Davies, 1994) and in fundamental research on gravel bed 168 armoring and bed material mobility (Dietrich et al., 1989; Parker and Klingeman, 1982; 169 Parker and Toro-Escobar, 2002). The GSD for the model was taken as the average 170 subsurface GSD measured by sieving volumetric bulk samples from the model (Church 171 and Hassan, 2002; Guerit et al., 2014). The grain sizes in the model ranged from 0.1-8 $172 \mathrm{~mm}$ with $\mathrm{D}_{10}=0.32 \mathrm{~mm} \mathrm{D}_{50}=1.18 \mathrm{~mm}$ and $\mathrm{D}_{90}=3.52 \mathrm{~mm}$. This is approximately a $1: 35$ 173 scale of the bulk distribution from the Sunwapta River, a proglacial gravel-bed braided 174 river in Alberta, Canada $\left(D_{50}=41 \mathrm{~mm}\right.$ ) (Figure 1) (Ashmore et al., 2011; Chew and 175 Ashmore, 2001). The model distribution was truncated at approximately $0.25 \mathrm{~mm}$ 
176 (equivalent to $8 \mathrm{~mm}$ at full scale) to avoid cohesive grain effects and preserve similarity

177 in flow resistance and bed morphology between the prototype and the model (Young and 178 Warburton, 1996). Bedload was collected in five metal sediment baskets, with a mesh 179 size of $0.1 \mathrm{~mm}$, which spanned the entire width of the model at the outlet.

180 Experimental Procedure

181 A generic braided morphology was self-generated from an initially straight channel at a 182 constant channel-forming discharge of $2.1 \mathrm{Ls}^{-1}( \pm 5 \%)$ and a slope of $1.5 \%$, which 183 approximates the slope of a reach of the Sunwapta River (Chew and Ashmore, 2001). 184 Following 24 hours of initial evolution to a braided morphology, three event hydrograph 185 experiments (referred to as A, B, and C) were completed (Figure 2). Discharges were 186 chosen to cover the range of discharges in a typical daily meltwater hydrograph of the 187 Sunwapta River so that the channel-forming discharge and peak flow of $2.1 \mathrm{Ls}^{-1}$ 188 approximates the average diurnal peak discharge $\left(15 \mathrm{~m}^{3} \mathrm{~s}^{-1}\right)$ in the prototype based on 189 the 1:35 scaling ratio and Froude scaling of discharge (Ashmore and Sauks, 2006; Egozi 190 and Ashmore, 2008). Each discharge step was run for at least 1 hour, split into 15 or 30 191 minute intervals for a total of 117 experimental runs and 27 discharge steps (Figure 2). 192 The time intervals were chosen to obtain a high temporal frequency of surveying while 193 still allowing for detectable morphological change to occur (Ashmore and Church, 1998), 194 so all runs were 15 minutes except for several at the lowest discharge $\left(0.7 \mathrm{Ls}^{-1}\right)$, which 195 were 30 minutes. The time base of a typical pro-glacial diurnal hydrograph is not 196 reproduced in the tests because of the experimental need to keep each step in the 197 hydrograph similar, at least 15 minutes long, and to focus on particle mobility and braiding 198 morpho-dynamics across the discharge range. 
199 At the end of each experimental run, the flow was turned off and once water was no longer

200 flowing over the downstream end, the bedload trapped in the downstream sediment

201 baskets was weighed using a load cell (precision $\pm 0.5 \%$ ) and then collected in sampling

202 bags. The waning flow phase may have introduced very minor amounts of additional

203 sediment into the baskets but these additions are expected to be negligible and consistent

204 across all measurements due to the relatively short waning period. Once the model

205 surface was drained of all standing water, high-resolution images of the dry bed surface

206 were taken for DEM generation via digital photogrammetry (discussed below). To

207 preserve the overall sediment balance of the model, a compensating volume of dry

208 sediment with the same GSD as the model subsurface was fed into the tail tank at the

209 end of each run to be fed into upstream end by a recirculating sediment pump during the

210 subsequent run. Therefore, the GSD of the sediment fed into the model during each run

211 was independent of the bedload collected during the previous run. Once the experiments

212 were completed, the collected bedload samples were dried and sieved at intervals of 0.5

213 phi from -2.5 to 2 phi $(5.6-0.25 \mathrm{~mm})$.

\section{Digital Photogrammetry: DEM Generation and Differencing}

215 Digital photos of the dry model surface were taken using 2 T5i Canon cameras with 20

$216 \mathrm{~mm}$ lenses mounted on a movable trolley 2.9-3 $\mathrm{m}$ above the model surface (depending

217 on exact location above the tilted flume). The camera orientation was slightly oblique so

218 that the images from each camera were fully-convergent across the flume. Images were

219 captured at approximately $0.4 \mathrm{~m}$ spacing along the flume (approximately $80 \%$ overlap of

220 successive images). Nominal pixel resolution on the sand surface was $0.7 \mathrm{~mm}$. Coded

221 targets (surveyed with sub-millimeter precision using a 2 second total station and 3D 
222 intersection calculation) in the model allowed for photos to be batch-processed using the

223 Structure-from-Motion software program, Agisoft PhotoScan, which was used to generate

224 orthophotos and DEMs of each surface with a $1.5 \mathrm{~mm}$ cell resolution and a vertical error

225 estimate of $( \pm 1.15 \mathrm{~mm})$. This error estimate was based on an analysis of range of

226 elevation differences in stable, flat areas of the model surface across all the DEMs.

227 Example DEMs from the beginning of each hydrograph can be seen in Figure 3.

228 The open-source software program Scilab was used for DEM differencing, so that areas

229 and volumes of topographic change could be quantified from the DEMs of Difference 230 (DoD). A simple uniform threshold for change detection of $3.6 \mathrm{~mm}$, which corresponds

231 with 3 standard deviations of the vertical error estimate of the final DEM surfaces $( \pm 1.15$ $232 \mathrm{~mm}$ ), was applied to each DEM of Difference (DoD) followed by a dilation filter, which 233 created a mask of 'change' (1) and 'no-change' (0). After the mask was applied to the raw 234 DoD, a final uniform threshold of $1 \mathrm{~mm}$, which corresponds with the approximate $\mathrm{D}_{50}$ of 235 the model, was applied. Therefore, the dilation method considers the neighbouring cells 236 of areas with a high probability of 'real change', thereby improving connectivity between 237 areas of morphological change while still reducing noise in the data. Each DoD was 238 cropped to remove targets and inlet effects, so that the final study area was restricted to 239 the downstream $14 \mathrm{~m}$ of the model. Reach-averaged estimates of the morphological 240 active depth and morphological active width were derived for each run by dividing the 241 total volume of change by the total active area, and dividing the total active area by the 242 reach length (i.e., $14 \mathrm{~m}$ ), respectively. In addition, reach-averaged wetted widths were 243 measured from manually digitized orthophotos of the water surface using ArcMap 10.4. 244 Finally, image texture analysis was used to map bed surface texture as a surrogate for 
245 bed material particle size at the beginning of each hydrograph, The method used was 246 based on a technique developed by Carbonneau et al., (2005) and described by Leduc

247 et al., (2015) for the same flume and bed sediment. The resulting data for "equivalent 248 texture" (Leduc et al., 2015) was a calibrated equivalent to the median particle size in a 7 $249 \times 7$ pixel moving window that provides a relative measure of differences in bed material 250 size spatially on the bed of the physical models.

\section{Results}

252 Bedload Transport Rate

253 Bedload transport rate $\left(\mathrm{Q}_{\mathrm{b}}\right)$ ranged from $0.02-11.70 \mathrm{gs}^{-1}$ (Figure 4). The mean bedload 254 transport rate and variability in transport rates increased with discharge so that the lowest 255 discharge of $0.7 \mathrm{I} \mathrm{s}^{-1}$ had the lowest mean transport rate of $0.12 \mathrm{gs}^{-1}$ (standard deviation, $256 \sigma=0.10)$ and the highest discharge $\left(2.1 \mathrm{Ls}^{-1}\right)$ had the highest mean transport rate at 3.60 $257 \mathrm{gs}^{-1}(\sigma=1.92)$ (Figure $\left.4 \mathrm{~b}\right)$. Abrupt changes in bedload transport rates occur around 1.14 $258 \mathrm{Ls}^{-1}$, below which transport rates are consistently very low $\left(<0.40 \mathrm{gs}^{-1}\right)$, and above which 259 transport rates increase with discharge (Figure 4a). This threshold discharge of $1.14 \mathrm{Ls}^{-1}$ 260 serves as a useful tool for describing the shift in bedload transport rates from negligible 261 to increasing with discharge. Although these experiments were not intended to investigate 262 the role of hysteresis in gravel-bed braided rivers, separating the bedload transport data 263 into rising and falling stages reveals no consistent hysteresis with changing discharge 264 (Figure 4b). 


\section{Fractional Transport}

266 Fractional transport rates were calculated as $q_{b i}=\left(p_{i}\right) q_{b}$, where $p i$ is the proportion of

267 each fraction $(I)$ found in the bedload transported $\left(q_{b}\right)$ for each run (Wilcock and McArdell, 268 1993). Across all discharges, bedload $D_{10}$ ranged from $0.07-0.57 \mathrm{~mm}$, $\mathrm{D}_{50}$ ranged from

$2690.48-1.41 \mathrm{~mm}$, and $D_{90}$ ranged from 1.15 to $3.57 \mathrm{~mm}$ (Figure 5). Overall, $\mathrm{D}_{10}$ was 270 relatively constant across all discharges and hydrographs except for runs at the lowest 271 discharge $\left(0.7 \mathrm{Ls}^{-1}\right)$, which had a mean $\mathrm{D}_{10}(\bar{x}=0.28 \mathrm{~mm})$ lower than all the other 272 discharges $(\bar{x}=0.35-0.41 \mathrm{~mm})$. While the mean D50 increased slightly with discharge 273 from 0.65 to $1.07 \mathrm{~mm}$ it plateaued around a mean value of $\sim 1 \mathrm{~mm}$, which was close to 274 the bulk $D_{50}$ of $1.18 \mathrm{~mm}$, above $1.35 \mathrm{Ls}^{-1}$. Of the three grain sizes investigated in detail, 275 the $D_{90}$ was the most responsive to increasing discharge and following the shape of the 276 hydrograph, with no obvious or systematic hysteresis effect (Figure 5). The mean D90 277 increased from $1.56 \mathrm{~mm}$ at the lowest discharge to $2.9 \mathrm{~mm}$ under the peak discharge 278 conditions, which was still lower than the mean bulk D9o $_{90} 3.52 \mathrm{~mm}$.

279 For all three hydrographs, individual grain sizes were grouped into 6 classes and plotted 280 as a mean percentage of the total bedload and as mean fractional transport rates for each

281 discharge in Figure 6. At the lowest discharge $\left(0.7 \mathrm{Ls}^{-1}\right)$, grains smaller than $1 \mathrm{~mm}$ 282 account for an average of $76 \%$ of the total bedload, while less than $5 \%$ of the bedload 283 was grains larger than $2 \mathrm{~mm}$. At higher discharges the GSD of the bedload is coarser, so 284 that at the highest discharges, fine grains $(<1 \mathrm{~mm})$ account for $\sim 47 \%$ of the bedload and 285 coarse grains (>2 mm) account for $\sim 20 \%$ of the bedload. Grains between 1-2 mm, which 286 includes the median of the subsurface $\left(D_{50}=1.18 \mathrm{~mm}\right)$, account for $\sim 30 \%$ of the total 287 bedload, regardless of discharge. The only exception is the lowest discharge, for which 
288 grains of $1-2 \mathrm{~mm}$ only account for an average of $19 \%$ of the total bedload. Only above $2891.14 \mathrm{Ls}^{-1}$ are the coarsest grains $(>5.6 \mathrm{~mm})$ detected in the bedload. Therefore, based on 290 the discharge steps investigated during these experiments, $1.14 \mathrm{Ls}^{-1}$ was the average 291 threshold discharge between partial and selective mobility.

\section{Comparison with Bed Material}

293 While the $D_{10}, D_{50}$, and $D_{90}$ varied within and between the hydrographs, even at the same 294 discharges (Figure 5), plotting the GSD of all 117 bedload samples together indicates the 295 steady shift in the grain size distributions as discharge increased (or decreased) between $2960.7 \mathrm{Ls}^{-1}$ to $2.1 \mathrm{Ls}^{-1}$ (Figure 7). The complete distribution of the bulk subsurface was rarely 297 reached in the bedload distributions and only at the channel-forming discharge of $2.1 \mathrm{Ls}^{-}$ $298{ }^{1}$ does bedload approach equal mobility with regards the subsurface. This graph confirms 299 that fine grains (i.e., $D_{10}$ ) are essentially fully mobilized regardless of discharge, while 300 coarser grains transition from a state of immobility at low discharges, through partial 301 mobilization towards full mobilization at the highest discharge.

\section{Transition towards Equal Mobility}

303 To investigate the changes in bed mobility with changing discharge, a pi/fi ratio was 304 plotted in Figure 8, where $p i$ is the frequency of grain size $i$ in the total bedload and $f i$ is 305 the frequency of grain size $i$ in the bulk distribution (Church and Hassan, 2002; Ferguson 306 et al., 1992). Partial mobility is characterized by the curve dropping towards zero for large 307 grain size while for selective mobility conditions, pi/fi decreases with grain size but 308 remains above zero for large grain sizes. For 'true' equal mobility, pi/fi equals 1 for all 309 grain sizes (Venditti et al., 2017). Figure 8 demonstrates that at higher discharge the 310 distributions shift from a state of marginal partial mobility present at low discharge, 
311 through a state of selective mobility around $1.14 \mathrm{Ls}^{-1}$ (i.e., where the coarsest fractions

312 are $0>p i / f i<1, \bar{x}=0.018, \sigma=0.037$ ), towards equal mobility, although strict true equal

313 mobility was never reached. In terms of individual grain sizes, $1 \mathrm{~mm}$ (i.e., the approximate

$\left.314 \mathrm{D}_{50}\right)$ transitions from a pi/fi of 0.4 at $0.7 \mathrm{Ls}^{-1}$ to 1.0 at the highest discharge. Also, fine

315 grains $(<0.5 \mathrm{~mm})$ are fully mobilized above a discharge of $0.83 \mathrm{Ls}^{-1}$. The coarsest grains 316 (i.e., $5.6 \mathrm{~mm}$ ) had a maximum pi/fi of 0.9 , but even at the highest discharge the average 317 pi/fi was only 0.27.

318 Using the ratio in the $\mathrm{D}_{90}$ of the surface ( $\left.\mathrm{D}_{905}\right)$ and bedload ( $\left.\mathrm{D}_{90 \mathrm{~L}}\right)$ as an indicator of bed 319 material mobility, there was a decrease in the mobility ratio with mean dimensionless 320 stream power $\left(\Omega^{*}\right)$ as defined by Lisle (1995):

$$
\Omega^{*}=\frac{\rho Q S}{\left(\rho_{s}-\rho\right) g^{1 / 2}\left(D_{50}\right)_{b}^{5 / 2}}
$$

321 Where $\rho$ is fluid density, $Q$ is discharge, $S$ is slope, $D_{50}$ is mean grain size, $\rho_{s}$ is sediment 322 density, $g$ is the acceleration due to gravity and $b$ is the average wetted width (Figure 9a).

323 This plot further demonstrates that true equal mobility generally not achieved with a 324 minimum average mobility ratio of 1.2 (best fit power function with exponent -0.60 ). A 325 similar relationship exists between the mobility ratio and bedload transport rate although 326 the shape of the function shows stronger non-linearity (Figure 9b) than with dimensionless 327 stream power.

\section{Linkages to Morphological Active Depth and Active Width}

329 DEMs of difference (DoDs) were used to estimate reach-averaged values of 330 morphological change for each experimental run (Figure 10). Due to poor image quality, 
3313 DEMs were removed from analysis for a total of 113 DoDs across all three hydrographs.

332 The DoDs demonstrate three emerging trends related to increasing discharge: 1) the

333 maximum morphological active depth increased; 2) the active area (i.e., total area of

334 erosion + total area of deposition) increased, and 3) the active areas were more 335 continuous and contiguous along the channel.

336 Results for the reach-averaged morphological active depth and morphological active 337 width can be seen in Figure 11. Across all discharges, the modal morphological active 338 depth was approximately $2.5 \mathrm{~mm}$ (Figure 11a). For the three lowest discharges (0.7- 0.93 $339 \mathrm{Ls}^{-1}$ ), the depth of scour was rarely (less than $20 \%$ of cases) greater than $3.5 \mathrm{~mm}$ (i.e., 340 D90 of the model subsurface). For the same three discharges, between $90-99 \%$ of the 341 active area had scour depths less than 2D90 $(6 \mathrm{~mm})$. At and above $1.14 \mathrm{Ls}^{-1}$, each of the 342 morphological active depth distributions became increasingly positively skewed, 343 reflecting the greater maximum depths of scour occurring with increasing discharge. At 344 the peak discharge of $2.1 \mathrm{Ls}^{-1}$, only $70 \%$ of the recorded active depths are below $6 \mathrm{~mm}$, 345 and the greatest active depths recorded were greater than $25 \mathrm{~mm}$, which is more than $34620 D_{50}$ and $7 D_{90}$ of the model GSD.

347 Between 0.7 and $0.93 \mathrm{Ls}^{-1}$, the reach-average morphological active width was very small 348 with averages between $0.02-0.03 \mathrm{~m}(\mathrm{~s}=0.007-0.01)$ (Figure 11b). At and above 1.14 $349 \mathrm{Ls}^{-1}$, the active width increased to an average of $0.06 \mathrm{~m}(\sigma=0.036)$ and continued to 350 increase with discharge to a mean of $0.38 \mathrm{~m}$ at the peak discharge of $2.1 \mathrm{Ls}^{-1}(\sigma=0.096)$. 351 Therefore, both the morphological active depth and width had a similar discharge 352 threshold as the transition from partial to selective mobility $\sim 1.14 \mathrm{Ls}^{-1}\left(\Omega^{*} \sim 70\right)$. 
353 Plots of $D_{10}, D_{50}$, and $D_{90}$ as a function of the bedload transport rate, reach-averaged 354 morphological active depth, and the reach-averaged morphological active width are 355 shown in Figure 12. Here the morphological active depth has been averaged for the entire $35614 \mathrm{~m}$ study reach, so there is one mean observation for each experimental run. Both $\mathrm{D}_{50}$ 357 and $D_{90}$ have a positive power relationship with bedload transport rate, morphological 358 active depth, and active width, but based on a least squares regression, D9o was more 359 sensitive to changes in transport rate and morphology with $R^{2}$ values between 0.656 3600.681 compared to the $D_{50}\left(R^{2}=0.509-0.604\right)$. As expected, $D_{10}$ was not sensitive to 361 either measure of morphological change $\left(R^{2}=0.0837-0.152\right)$, or bedload transport rate $362\left(R^{2}=0.150\right)$ because fine grains were fully mobilized under all discharge conditions 363 (Figure 5). Furthermore, at very low discharges, when the bed was only partially mobile, 364 the morphological active depth and active width are small, confirming that the finer tail of 365 the gravel bed material moving over the bed results in little detectable morphological 366 change. Separating rising and falling stage data shows no systematic hysteresis effect in 367 the data (Figure 12).

368 To investigate differences between the three hydrographs, the initial bed hypsometry (see 369 also Redolfi et al., 2018) and bed texture was plotted for each hydrograph (Figure 13 and 370 see also Figure 3). The hypsometry analysis indicates that the initial topography of 371 hydrographs $A$ and $C$ were nearly identical, but differed for $B$, although all three lie within 372 the overall range of variability for the entire dataset. In terms of equivalent bed texture, 373 the three hydrographs began with nearly identical distributions, all of which fall within the 374 range of variability across all observations (Figure 13b). In addition to indicating that there 375 was no apparent effect from running hydrograph A following a period of constant 
376 discharge evolution, these results highlight the inherent complexity and variability of

377 braided river processes.

\section{Discussion}

379 In the physical model of a generic gravel-bed braided river, fractional transport rates, grain 380 size distributions, and pi/fi ratios transition from a state of partial mobility to selective 381 mobility at relatively low discharges and gradually approach near-equal mobility at peak 382 channel-forming discharges and highest rates of morphological change.

383 In terms of individual grain sizes, the results showed that while $D_{10}$ was essentially fully 384 mobile across all experimental discharges, both $D_{50}$ and $D_{90}$ increased with discharge.

$385 D_{50}$ levelled off as it approached $D_{50}$ of the model subsurface bulk sediment, indicating 386 full mobilization of those fractions above discharges of $1.35 \mathrm{Ls}^{-1}$. D90 increased with 387 discharge but did not level off, even at the channel-forming discharge of $2.1 \mathrm{Ls}^{-1}$, 388 indicating only partial mobilization of coarse grains and therefore selective mobility of the 389 bed. It is possible that with slightly higher discharges that the coarse grains would become

390 more frequently fully mobilized. The results are similar to Ashworth et al. (1992) in a 391 braided chute-bar structure, who found that while $D_{50}$ was relatively constant, both 392 spatially and temporally, $D_{\max }$ was sensitive to increasing flow strength through a single 393 braided anabranch in the field. This is also consistent with earlier observations of 394 Ashworth and Ferguson $(1986,1989)$ in a braided gravel outwash channel.

395 Looking at the complete GSD of the hydrographs demonstrated that the transition from 396 partial mobility towards equal mobility was gradual and variable for each hydrograph. 397 Since the peak flows modelled here were the same, differences in the GSDs likely reflect 
398 inherent variability in braiding processes and bedload response. In all cases, active 399 braiding occurred for much of the hydrograph duration so that bed configuration and bed 400 texture constantly varied. Local scour, channel shifting, bar development, and avulsion 401 may all cause temporal variation in bedload transport rates and sources of bedload even 402 at constant discharge (Ashmore, 1988; Bertoldi et al., 2009; Hoey, 1992; Peirce et al., 403 2018). For instance, there was a decrease in the D90 of hydrograph $B$ (Figure 5) after the 404 first four runs at peak discharge, possibly indicating a temporary decrease in the 405 availability of coarse grain. This decrease in $D_{90}$ in hydrograph B was also associated 406 with 23\% decrease in both the morphological active depth and active width, highlighting 407 the additional possible effect of morphological effects on particle mobility. During the 408 subsequent hydrograph, hydrograph $\mathrm{C}$, the morphology had shifted (Figure 3) through 409 braiding processes, providing a fresh source of coarse grains.

410 These results follow previous research that suggests that there is a range of 'formative' 411 or morphologically significant discharges over which bedload is transported depending 412 on the morphological units (e.g., primary and secondary channels, bars etc.) being 413 considered, which could also contribute to the overlapping GSDs for different discharges 414 (Figure 7) (Mao and Surian, 2010; Surian et al., 2009). The differences in the three 415 hydrographs highlight the importance of sampling multiple hydrographs, even over a 416 similar morphology and small range of discharges, to capture the variability in GSDs and 417 antecedent conditions of flow and channel morphology (Kociuba and Janicki, 2015; 418 Powell et al., 2001b). It also points to the need for further model experiments to evaluate 419 the effects of hydrograph duration and shape, as well as the related inherent variability in 420 braiding morpho-dynamics. 
421 The fractional transport analysis indicated the largest grain sizes $(>5.6 \mathrm{~mm}$ ) only became

422 transported above $1.14 \mathrm{Ls}^{-1}\left(\Omega^{*}=\sim 70\right)$ in the model. This discharge, which would

423 represent approximately $8 \mathrm{~m}^{3} \mathrm{~s}^{-1}$ in the prototype river, is only $\sim 50 \%$ of the channel-

424 forming (i.e., peak discharge) of $2.1 \mathrm{Ls}^{-1}$ in the flume or $\sim 15 \mathrm{~m}^{3} \mathrm{~s}^{-1}$ in the prototype. These

425 results align with observations by Surian et al. (2009) and Mao and Surian (2010) who

426 found that substantial morphological change and bed material mobilization occurred in

427 the primary and secondary channels of gravel-bed rivers at discharges as low as $20-50 \%$

428 of bankfull. Together, these results demonstrate that some gravel-bed braided rivers may

429 transition to selective mobility (i.e., the mobilization of coarse grains) at lower discharges

430 than single-threaded gravel-bed rivers which may need discharges as high as $80 \%$ of

431 the bankfull discharge before gravel grains are mobilized, due to the need to mobilize the

432 coarser grains in the surface layer (Ryan et al., 2002). In braiding rivers, the wide range

433 of bed shear stress (Nicholas, 2000; Bertoldi et al., 2009) and local scour may produce

434 high mobility at relatively low discharge in particular areas of the bed. Furthermore, as the

435 threshold discharge between partial and selective mobility here was defined as

436 approximately half of the channel-forming flow, the braided rivers modelled were

437 dominated by selective mobility over almost all bed-mobilizing discharges. This is in

438 contrast to the rather ubiquitous characterization of gravel-bed rivers as being only

439 partially mobile due to a large population of immobile coarse grains that may only be

440 mobilized at very high flows (Haschenburger and Wilcock, 2003; Venditti et al., 2017)

441 falling into Church's (2006) category of "threshold channel 0.04+".

442 The relation between bed mobility and morphological active layer dimensions has not 443 been thoroughly investigated for braiding rivers. In stable single-thread rivers, Wilcock 
444 and McArdell (1997) and Haschenburger and Wilcock (2003) found that full surface 445 mobilization (i.e. selective mobility) of a gravel-bed was associated with active layer depth 446 of $\sim 2 \mathrm{D}_{90}$. Similarly, Lisle (1995) found that the convergence of the bedload and bed 447 material grain size was associated with large active layer thicknesses (e.g., 4-12D84) and 448 mobilization of large portions of the streambed area. The results here agree well with 449 Wilcock and McArdell (1997) so that below $1.14 \mathrm{Ls}^{-1}$, when the bed is only partially 450 mobilized and coarse grains are essentially immobile, the average morphological active 451 depth was rarely $\left(<10 \%\right.$ of observations) greater than the 2Dgo of $6 \mathrm{~mm}$. Once $1.14 \mathrm{Ls}^{-1}$ 452 was reached, the morphological active depth increased with discharge so that scour 453 depths greater than $25 \mathrm{~mm}$ (7D90) were common above discharges of $1.65 \mathrm{Ls}^{-1}$, 454 promoting full mobilization of the coarse bed material with increasing flow strength, similar 455 to the results of Lisle (1995). Furthermore, the modal scour depth during bedload 456 transport was close to $2.5 \mathrm{~mm}$ regardless of discharge. This suggests that transitions 457 towards selective mobility and increases in bedload are not just due to increases in local 458 maximum scour depth, but also the increase in the total morphologically active area of 459 the bed (i.e., the morphological active width). This idea is supported with recent findings 460 by Gardner et al. (2017) who found that confluence scours, which are commonly the 461 locations of deepest scour, only occupied $21 \%$ of the active area of a modelled braided 462 gravel river bed.

463 From a visual inspection of the DoDs, the morphological active width expands and 464 becomes more continuous along the channel with increasing flow strength (and see 465 Peirce et al., 2018). Plots of the active width against discharge show a general threshold 466 of $1.14 \mathrm{Ls}^{-1}$, below which the active with is narrow ( $<3 \%$ of the wetted width) and relatively 
467 constant, and above which the active width expands linearly with increasing discharge to 468 over $20 \%$ of the wetted width at high discharge. Overall, the results on morphological 469 change indicate that areas of the bed do not remain immobile for long periods of time, so 470 that the surface and subsurface are continuously being accessed and mobilized at 471 relatively low discharges ( $>1.14 \mathrm{Ls}^{-1}$ in this case). Furthermore, increases in shear stress, 472 while important for grain entrainment, may not be the only driver of bedload transport in 473 morphologically-driven rivers like braided rivers. Again, a modal scour depth around 2.5

$474 \mathrm{~mm}$ regardless of discharge suggests that it is not just an increase in shear stress at 475 higher discharges but the increase in the area experiencing shear stresses above critical 476 that is important (Bertoldi et al., 2009). This idea complements the findings of 477 Haschenburger and Wilcock (2003) who described the transition of a gravel-bed river 478 from partial to selective mobility as active areas of the bed expanded, and Ashmore \& 479 Sauks (2006) and Bertoldi et al. (2009) who found that braided rivers accommodate 480 increases in discharge by increasing wetted width (and therefore morphological active 481 width) with less change in mean water depth and mean velocity.

482 Finally, for the first time in braided river research, the relationship between morphological 483 measurements of the morphological active depth and active width were compared to 484 different grain size parameters for a large dataset. The results confirm that the movement 485 of large grains, like $\mathrm{D}_{90}$, are directly linked to changes in morphology in response to 486 discharge forcing, specifically the vertical expansion of active depth and lateral expansion 487 of the active width. This is consistent with greater braiding activity occurring at higher 488 discharges during which lateral bank erosion, bar migration, bed scour at anabranch 489 confluences, avulsion, and other braiding processes are more active (Wheaton et al., 
490 2013). Also, the increased area of active layer turnover, as shown in the morphological 491 change data, differs from the largely vertical exchange and limited bed scour observed in 492 stable single channels and straight-walled flumes (Ashmore et al., 2018). These results 493 suggest that in morphologically dynamic gravel-bed braided rivers, increases in bedload 494 transport and the coarse grain mobilization above the threshold discharge is mediated by 495 the availability of a wide range of sizes at the surface and subsurface as well as and the 496 constant changes in the morphological active layer providing access to new sediment 497 sources, laterally and vertically within the channel.

498 While these experiments provide interesting insights into the linkages between discharge, 499 bedload grain size distributions and transport rates, and channel morphology in braided 500 rivers, there are other considerations that should be investigated in the future. For 501 example, while scale models have been vital for investigating grain size distributions and 502 bed mobility relationships in gravel-bed rivers (e.g., Parker et al., 1982; Dietrich et al., 503 1989; Wilcock and McArdell, 1993), models often require simplifications that might not 504 perfectly reflect the natural prototype. In this case, the grain size distribution of the model 505 was truncated below $0.25 \mathrm{~mm}$ to avoid cohesion effects. Additional studies should 506 investigate the role of fine grains on the GSD and bedload transport rates in braided 507 rivers, as fines are known to enhance the mobilization of coarse grains and rates of 508 bedload transport (Iseya and Ikeda, 1987; Venditti et al., 2010). Furthermore, given the 509 possible impacts of different hydrograph structures on experimental outcomes, additional 510 work should be done investigating more hydrograph structures as well as long-term (e.g., 511 seasonal and annual) hydrologic regimes with a larger range of discharges. While the 512 data show no clear hysteresis in bedload, morphological change which is consistent with 
513 recent hydrograph experiments of Redolfi et al., (2018), or bedload grain size, there is a

514 possibility to examine the consistency and reasons for this effect in braiding rivers in more

515 detail in the future. Finally, this research may be able to improve the numerical modelling

516 of bedload transport and river morphodynamics rates in braided rivers (e.g., Williams et

517 al., 2016b; Javernick et al., 2018). For instance, recent results from numerical morpho-

518 dynamic modeling of braiding suggest that bed mobility may have a substantial effect on

519 braiding morphology and dynamics (Sun et al., 2015) and data like those collected in

520 these experiments could be used for validation and testing of these fundamental

521 processes. On the basis of the current results this could be extended to understanding

522 the role of surface coarsening (or lack of it) and bed material grain size distribution on

523 morphological active layer dimensions and bedload grain size distributions in gravel 524 braiding rivers.

525 Overall, the results point to a fundamental relationship between bed material mobility and 526 morphological dynamics at varying discharge in some gravel braiding rivers. In order for 527 significant morphological change to occur, as it does even at moderate discharges, much 528 of the bed material needs to be mobilized. Therefore, the magnitude and frequency of 529 morphological change are an indication of bed material mobility and without it active 530 braiding would not occur (Ashmore et al., 2018). Specifically, the results of these 531 experiments show that in braiding, full mobility of the median size occurs at moderate 532 discharge but that large morphological change is associated with mobility of the coarse 533 fractions. Limiting the mobility of the coarse fractions is then expected to reduce 534 morphological dynamics and stabilize active braiding as shown recently by Mackenzie 535 and Eaton (2017). 


\section{Conclusions}

537 Physical model experiments were used to explore the evolution of grain size distributions 538 and bed mobility in gravel-bed rivers in complex multi-threaded braided systems. Given

539 the challenges to collecting simultaneous bedload transport and topographic data in the 540 field, a physical model made it possible to measure bedload transport rates and changes

541 in morphology over three event hydrographs similar to those found in a pro-glacial gravel542 bed braided river. The model braided rivers transitioned from partial mobility to selective

543 mobility at discharges above $\sim 50 \%$ of peak discharge, and approached equal mobility at 544 the highest (i.e., diurnal peak/channel-forming) discharges. This contrasts with stable, 545 single-threaded gravel-bed rivers, which are normally dominated by partial mobility, even 546 at bankfull discharges. The transition from partial mobility to selective mobility 547 corresponded to the lower threshold for detectable morphological change and a 548 substantial increase in bedload transport rates at approximately $50 \%$ of peak discharge, 549 or dimensionless stream power (Lisle, 1995) of 70 . Morphological change and bed 550 material transport and mobility are closely connected as discharge changes. With 551 increasing (decreasing) discharge the morphological active layer progressively expands 552 (contracts) both vertically and laterally, with active layer depth reaching maximum values 553 up to 9 times $\mathrm{D}_{90}$. The highest particle mobility states are associated with the highest 554 discharge and the most intense rates and greatest extents of morphological change; the 555 most active braiding occurs when coarse grains are mobilized and vice versa.

556 These results contribute to the overall understanding of braided river morphodynamics by 557 demonstrating the strong linkages between the thresholds for detectable morphological 558 change, bedload transport rates, and coarse grain mobilization. Until now, there have 
559 been no studies, in the field or flume, that have been able to link discharge variation and

560 channel morphology with grain size distributions in gravel-bed braided rivers in this way.

561 In turn, these results will have implications for assessing and modelling bedload transport

562 and channel stability in braiding rivers, and show the importance of extending analyses

563 of bedload dynamics to a wider range of channel types..

\section{Acknowledgements}

565 This research was supported by a Natural Sciences and Engineering Research Council

566 Discovery Grant to P. Ashmore and flume construction was supported by the Canada

567 Foundation for Innovation and Newalta Resources Inc. Additional funding support was

568 provided by the Vanier Canada Graduate Scholarship awarded to S. Peirce. Thank you

569 to everyone who assisted with the experiments, especially Lara Middleton and Danielle

570 Barr.

\section{References}

572 Ashmore P. 1988. Bed load transport in braided gravel-bed stream models. Earth

573 Surface Processes and Landforms 13: 677-695.DOI: 10.1002/esp.3290130803

574 Ashmore P. 2013. Morphology and Dynamics of Braided Rivers. In Treatise on

575 Geomorphology, Shroder J and Wohl E (eds). Elsevier: San Diego; 289-312.

576 Ashmore P, Bertoldi W, Tobias Gardner J, Gardner JT. 2011. Active width of gravel-bed

577 braided rivers. Earth Surface Processes and Landforms 36: 1510-1521.DOI:

$578 \quad 10.1002 /$ esp.2182

579 Ashmore P, Church M. 1998. Sediment transport and river morphology: a paradigm for

580 study. In Gravel-Bed Rivers in the Environment , . 115-148. 
581 Ashmore P, Peirce S, Leduc P. 2018. Expanding the "Active Layer": Discussion of 582 Church and Haschenburger (2017) What is the "Active Layer"? Water Resources

583 Research 53, 5-10, Doi:10.1002/2016WR019675. Water Resources Research 54:

584 1425-1427.DOI: 10.1002/2017WR022438

585 Ashmore P, Sauks E. 2006. Prediction of discharge from water surface width in a 586 braided river with implications for at-a-station hydraulic geometry. Water Resources 587 Research 42: 1-11.DOI: 10.1029/2005WR003993

588 Ashmore PE. 1982. Laboratory modelling of gravel braided stream morphology. Earth 589 Surface Processes and Landforms 7: 201-225.DOI: 10.1002/esp.3290070301

590 Ashworth PJ, Ferguson RI. 1986. Interrelationships of Channel Processes, Changes 591 and Sediments in a Proglacial Braided River. Geografiska Annaler. Series A, Physical 592 Geography 68: 361.DOI: 10.2307/521527

593 Ashworth PJ, Ferguson RI. 1989. Size-selective entrainment of bed load in gravel bed 594 streams. Water Resources Research 25: 627-634.DOI: 10.1029/WR025i004p00627

595 Ashworth PJ, Ferguson RI, Ashmore P, Paola C, Powell DM, Prestegaards KL, 596 Prestegaard KL, Prestegaards KL. 1992. Measurements in a Braided River chute and 597 lobe: 2 . Sorting of bed load during entrainment, transport, and deposition. Water 598 Resources Research 28: 1887-1896.DOI: 10.1029/92WR00702

599 Bertoldi W, Ashmore P, Tubino M. 2009. A method for estimating the mean bed load 600 flux in braided rivers. Geomorphology 103: 330-340.DOI:

601 10.1016/j.geomorph.2008.06.014

602 Bluck BJ. 1979. Structure of coarse grained braided stream alluvium. Earth and 603 Environmental Science Transactions of the Royal Society of Edinburgh 70: 181-221. 
604 Brasington J, Rumsby BT, Mcvey RA. 2000. Monitoring and modelling morphological 605 change in a braided gravel-bed river using high resolution GPS-based survey. Earth 606 Surface Processes and Landforms 25: 973-990.DOI: 10.1002/1096-9837(200008)25 607 Bunte K, Abt SR. 2001. Summary for Policymakers. In Climate Change 2013 - The 608 Physical Science Basis, Intergovernmental Panel on Climate Change (ed). Cambridge 609 University Press: Cambridge; 1-30.

610 Carbonneau PE, Bergeron N, Lane SN. 2005. Automated grain size measurements

611 from airborne remote sensing for long profile measurements of fluvial grain sizes. Water

612 Resources Research 41: 1-9.DOI: 10.1029/2005WR003994

613 Carson MA, Griffiths GA. 1987. Bedload Transport in Gravel Channels. Journal of 614 Hydrology New Zealand 26

615 Chew L., Ashmore P. 2001. Channel adjustment and a test of rational regime theory in 616 a proglacial braided stream. Geomorphology 37: 43-63.DOI: 10.1016/S0169-

$617555 \times(00) 00062-3$

618 Church M. 2006. Bed Material Transport and the Morphology of Alluvial River Channels.

619 Annual Review of Earth and Planetary Sciences 34: 325-354.DOI:

620 10.1146/annurev.earth.33.092203.122721

621 Church M, Haschenburger JK. 2017. What is the "active layer"? Water Resources

622 Research 53: 5-10.DOI: 10.1002/2016WR019675

623 Church M, Hassan MA. 2002. Mobility of bed material in Harris Creek. Water Resources

624 Research 38: 19-1-19-12.DOI: 10.1029/2001WR000753

625 Davies T. 1987. Problems of bed load transport in braided gravel-bed rivers. In

626 Sediment Transfer in Gravel-Bed Rivers, Thorne CR, Bathurst JC, and Hey RD (eds). 
627 John Wiley \& Sons; 793-811.

628 Dietrich WE, Kirchner JW, Ikeda H, Iseya F. 1989. Sediment supply and the

629 development of the coarse surface layer in gravel-bedded rivers. Nature 340: 215-

630 217.DOI: $10.1038 / 340215 \mathrm{a} 0$

631 Egozi R, Ashmore P. 2008. Defining and measuring braiding intensity. Earth Surface

632 Processes and Landforms 33: 2121-2138.DOI: 10.1002/esp.1658

633 Ferguson RI. 1987. Hydraulic and Sedimnetary Controls of Channel Pattern. In River

634 channels, Richards K (ed). Basil Blackwell; 129-158.

635 Ferguson RI, Ashmore P, Ashworth PJ, Paola C, Prestegaard KL. 1992. Measurements

636 in a Braided River chute and lobe: 1. Flow pattern, sediment transport, and channel

637 change. Water Resources Research 28: 1877-1886.DOI: 10.1029/92WR00700

638 Gardner JT, Ashmore P. 2011a. Geometry and grain-size characteristics of the basal

639 surface of a braided river deposit. Geology 39: 247-250.DOI: 10.1130/G31639.1

640 Gardner JT, Ashmore P. 2011b. Geometry and grain-size characteristics of the basal

641 surface of a braided river deposit. Geology 39: 247-250.DOI: 10.1130/G31639.1

642 Gardner T, Ashmore P, Leduc P. 2017. Morpho-sedimentary characteristics of proximal

643 gravel braided river deposits in a Froude-scaled physical model. Sedimentology 38: 42644 49.DOI: $10.1111 /$ sed.12409

645 Guerit L, Barrier L, Narteau C, Métivier F, Liu Y, Lajeunesse E, Gayer E, Meunier P,

646 Malverti L, Ye B. 2014. The grain-size patchiness of braided gravel-bed streams -

647 Example of the Urumqi River (northeast Tian Shan, China). Advances in Geosciences

648 37: 27-39.DOI: 10.5194/adgeo-37-27-2014

649 Haschenburger JK, Wilcock PR. 2003. Partial transport in a natural gravel bed channel. 
650 Water Resources Research 39: 1-9.DOI: 10.1029/2002WR001532

651 Hoey T. 1992. Temporal variations in bedload transport rates and sediment storage in

652 gravel-bed rivers. Progress in Physical Geography 16: 319-338.DOI:

$653 \quad 10.1177 / 030913339201600303$

654 Hoey TB, Sutherland AJ. 1991. Channel morphology and bedload pulses in braided 655 rivers: a laboratory study. Earth Surface Processes and Landforms 16: 447-462.DOI:

$656 \quad 10.1002 /$ esp.3290160506

657 Iseya F, Ikeda H. 1987. Pulsations in Bedload Transport Rates Induced by a 658 Longitudinal Sediment Sorting: A Flume Study Using Sand and Gravel Mixtures.

659 Geografiska Annaler. Series A, Physical Geography 69: 15.DOI: 10.2307/521363

660 Javernick L, Redolfi M, Bertoldi W. 2018. Evaluation of a numerical model's ability to 661 predict bed load transport observed in braided river experiments. Advances in Water 662 Resources 115: 207-218.DOI: 10.1016/j.advwatres.2018.03.012

663 Kasprak A, Wheaton JM, Ashmore P, Hensleigh JW, Peirce S. 2015. The relationship

664 between particle travel distance and channel morphology: Results from physical models 665 of braided rivers. Journal of Geophysical Research: Earth Surface 120: 55-74.DOI:

$666 \quad 10.1002 / 2014 J F 003310$

667 Kociuba W, Janicki G. 2015. Changeability of Movable Bed-Surface Particles in Natural, 668 Gravel-Bed Channels and Its Relation to Bedload Grain Size Distribution (Scott River, 669 Svalbard). Geografiska Annaler: Series A, Physical Geography 97: 507-521.DOI:

$670 \quad 10.1111 /$ geoa.12090

671 Laronne J. B, Reid I, Yitshak Y, Frostick LE. 1994. The non-layering of gravel

672 streambeds under ephemeral flood regimes. Journal of Hydrology 159: 353-363.DOI: 
$673 \quad 10.1016 / 0022-1694(94) 90266-6$

674 Laronne J. B, Reid L. 1993. Very high rates of bedload sediment transport by

675 ephemeral desert rivers. Nature 366: 148-150.DOI: 10.1038/366148a0

676 Leduc P, Ashmore P, Gardner JT. 2015. Grain sorting in the morphological active layer

677 of a braided river physical model. Earth Surface Dynamics 3: 577-585.DOI:

$678 \quad 10.5194 /$ esurf-3-577-2015

679 Lisle TE. 1995. Particle size variations between bed load and bed material in natural 680 gravel bed channels. Water Resources Research 31: 1107-1118.

681 Lisle TE, Nelson JM, Pitlick J, Madej MA, Barkett BL. 2000. Variability of bed mobility in 682 natural, gravel-bed channels and adjustments to sediment load at local and reach 683 scales. Water Resources Research 36: 3743-3755.DOI: 10.1029/2000WR900238

684 Lugo GAG, Bertoldi W, Henshaw AJ, Gurnell AM. 2015. The effect of lateral 685 confinement on gravel bed river morphology. Water Resources Research 51: 7145686 7158.DOI: 10.1002/2015WR017081

687 MacKenzie LG, Eaton BC. 2017. Large grains matter: contrasting bed stability and 688 morphodynamics during two nearly identical experiments. Earth Surface Processes and 689 Landforms 42: 1287-1295.DOI: 10.1002/esp.4122

690 Mao L, Surian N. 2010. Observations on sediment mobility in a large gravel-bed river.

691 Geomorphology 114: 326-337.DOI: 10.1016/j.geomorph.2009.07.015

692 Morgan JA, Brogan DJ, Nelson PA. 2016. Application of Structure-from-Motion

693 photogrammetry in laboratory flumes. Geomorphology 276: 125-143.DOI:

694 10.1016/j.geomorph.2016.10.021

695 Mueller ER, Pitlick J. 2013. Sediment supply and channel morphology in mountain river 
696 systems: 1. Relative importance of lithology, topography, and climate. Journal of

697 Geophysical Research: Earth Surface 118: 2325-2342.DOI: 10.1002/2013JF002843

698 Mueller ER, Pitlick J. 2014. Sediment supply and channel morphology in mountain river

699 systems: 2. Single thread to braided transitions. Journal of Geophysical Research:

700 Earth Surface 119: 1516-1541.DOI: 10.1002/2013JF003045

701 Parker G. 2008. Transport of Gravel and Sediment Mixtures. In Sedimentation

702 Engineering: Processes, Measurements, Modeling, and Practice, Garcia M (ed).

703 American Society of Civil Engineers: Reston, VA; 165-252.

704 Parker G, Dhamotharan S, Stefan H. 1982. Model experiments on mobile, paved gravel

705 bed streams. Water Resources Research 18: 1395-1408.DOI:

$706 \quad 10.1029 /$ WR018i005p01395

707 Parker G, Klingeman PC. 1982. On why gravel bed streams are paved. Water

708 Resources Research 18: 1409-1423.DOI: 10.1029/WR018i005p01409

709 Parker G, Toro-Escobar CM. 2002. Equal mobility of gravel in streams: The remains of

710 the day. Water Resources Research 38: 46-1-46-8.DOI: 10.1029/2001WR000669

711 Peirce S, Ashmore P, Leduc P. 2018. The Variability in the Morphological Active Width:

712 Results from Physical Models of Gravel-Bed Braided Rivers. Earth Surface Processes

713 and Landforms : 1-38. DOI: 10.1002/esp.4400

714 Piegay H, Grant G, Nakamura F, Trustrum N. 2006. Braided River Management: from

715 Assessment of River Behaviour to Improved Sustainable Development. In Braided

716 Rivers: Process, Deposits, Ecology and Management , . Blackwell Publishing Ltd.:

717 Oxford, UK; 257-275.

718 Powell DM, Ashworth PJ. 1995. Spatial Pattern of Flow Competence and Bed Load 
719 Transport in a Divided Gravel Bed River. Water Resources Research 31: 741-752.DOI:

$720 \quad 10.1029 / 94 W R 02273$

721 Powell DM, Reid I, Laronne B. 2001a. Evolution of bed load grain size distribution with

722 increasing flow strength and the effect of flow duration on the caliber of bed load

723 sediment yield in ephemeral gravel bed rivers. Water Resources Research 37: 1463-

7241474.

725 Powell DM, Reid I, Laronne J. BB. 2001b. Evolution of bed load grain size distribution 726 with increasing flow strength and the effect of flow duration on the caliber of bed load 727 sediment yield in ephemeral gravel bed rivers. Water Resources Research 37: 1463-

728 1474.DOI: 10.1029/2000WR900342

729 Recking A, Piton G, Vazquez-Tarrio D, Parker G. 2016. Quantifying the Morphological 730 Print of Bedload Transport. Earth Surface Processes and Landforms 41: 809-822.DOI:

$731 \quad 10.1002 /$ esp.3869

732 Redolfi M, Bertoldi W, Tubino M, Welber M. 2018. Bed Load Variability and Morphology

733 of Gravel Bed Rivers Subject to Unsteady Flow: A Laboratory Investigation. Water

734 Resources Research 54: 842-862.DOI: 10.1002/2017WR021143

735 Ryan SE, Porth LS, Troendle CA. 2002. Defining phases of bedload transport using

736 piecewise regression. Earth Surface Processes and Landforms 27: 971-990.DOI:

$737 \quad 10.1002 /$ esp.387

738 Smith ND. 1974. Sedimentology and Bar Formation in the Upper Kicking Horse River, a

739 Braided Outwash Stream. The Journal of Geology 82: 205-223.

740 Sun J, Lin B, Yang H. 2015. Development and application of a braided river model with

741 non-uniform sediment transport. Advances in Water Resources 81: 62-74.DOI: 
$742 \quad$ 10.1016/j.advwatres.2014.12.012

743 Surian N, Mao L, Giacomin M, Ziliani L. 2009. Morphological effects of different

744 channel- forming discharges in a gravel-bed river. Earth Surface Processes and

745 Landforms 34: 1093-1107.DOI: 10.1002/esp.1798

746 Venditti JG, Dietrich WE, Nelson PA, Wydzga MA, Fadde J, Sklar L. 2010. Mobilization

747 of coarse surface layers in gravel-bedded rivers by finer gravel bed load. Water

748 Resources Research 46: 1-10.DOI: 10.1029/2009WR008329

749 Venditti JG, Nelson PA, Bradley RW, Haught D, Gitto AB. 2017. Bedforms, Structures,

750 Patches, and Sediment Supply in Gravel-Bed Rivers. In Gravel-Bed Rivers , . John

751 Wiley \& Sons, Ltd: Chichester, UK; 439-466.

752 Warburton J, Davies T. 1994. Variability of bedload transport and channel morphology

753 in a braided river hydraulic model. Earth Surface Processes and Landforms 19: 403-

754 421.DOI: 10.1002/esp.3290190503

755 Wheaton JM, Brasington J, Darby SE, Kasprak A, Sear DA, Vericat D. 2013.

756 Morphodynamic signatures of braiding mechanisms as expressed through change in

757 sediment storage in a gravel-bed river. Journal of Geophysical Research: Earth Surface

758 118: 759-779.DOI: 10.1002/jgrf.20060

759 Wilcock PR, McArdell BW. 1993. Surface-based fractional transport rates: Mobilization

760 thresholds and partial transport of a sand-gravel sediment. Water Resources Research

761 29: 1297-1312.DOI: 10.1029/92WR02748

762 Wilcock PR, McArdell BW. 1997a. Partial transport of a sand/gravel sediment. Water

763 Resources Research 33: 235-245.DOI: 10.1029/96WR02672

764 Wilcock PR, McArdell BW. 1997b. Partial transport of a sand / gravel sediment flume. 
765 Water Resources Research 33: 235-245.

766 Williams RD, Brasington J, Hicks DM. 2016a. Numerical Modelling of Braided River

767 Morphodynamics: Review and Future Challenges. Geography Compass 10: 102-

768 127.DOI: $10.1111 / \mathrm{gec} 3.12260$

769 Williams RD, Measures R, Hicks DM, Brasington J. 2016b. Assessment of a numerical

770 model to reproduce event-scale erosion and deposition distributions in a braided river.

771 Water Resources Research 52: 6621-6642.DOI: 10.1002/2015WR018491

772 Williams RD, Rennie CD, Brasington J, Hicks DM, Vericat D. 2015a. Linking the spatial

773 distribution of bed load transport to morphological change during high-flow events in a

774 shallow braided river. Journal of Geophysical Research: Earth Surface 120: 604-

775 622.DOI: 10.1002/2014JF003346

776 Williams RD, Rennie CD, Brasington J, Hicks DM, Vericat DD. 2015b. Linking the

777 spatial distribution of bed load transport to morphological change during high-flow

778 events in a shallow braided river. Journal of Geophysical Research: Earth Surface 120:

779 604-622.DOI: 10.1002/2014JF003346

780 Young WJ, Warburton J. 1996. Principles and practice of hydraulic modelling of braided

781 gravel-bed rivers. Journal of Hydrology New Zealand 35: 175-198.DOI: 10.1016/S0301-

$782 \quad 9322(97) 80098-5$

783

784

785 


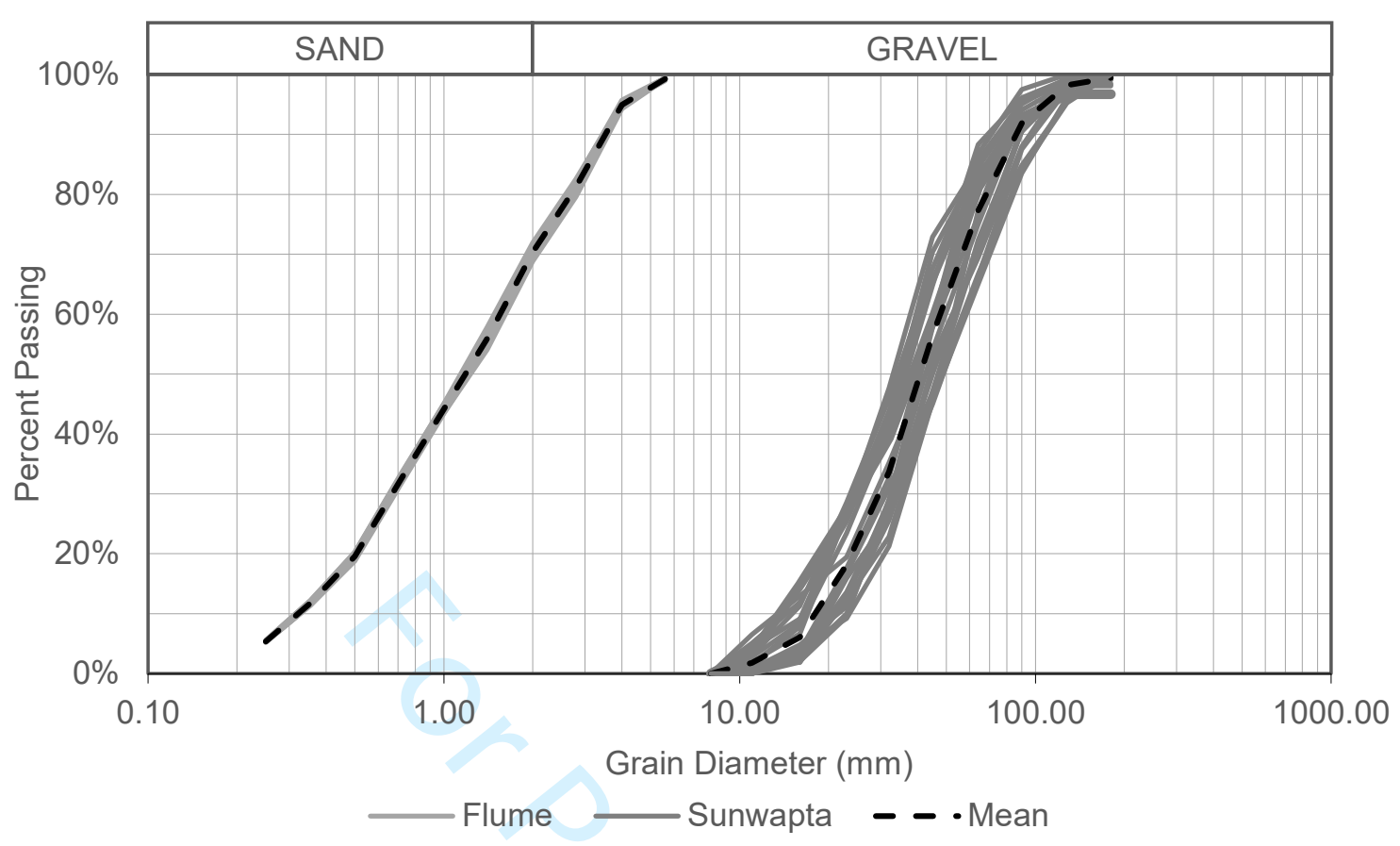

http://mc.manuscriptcentral.com/esp 


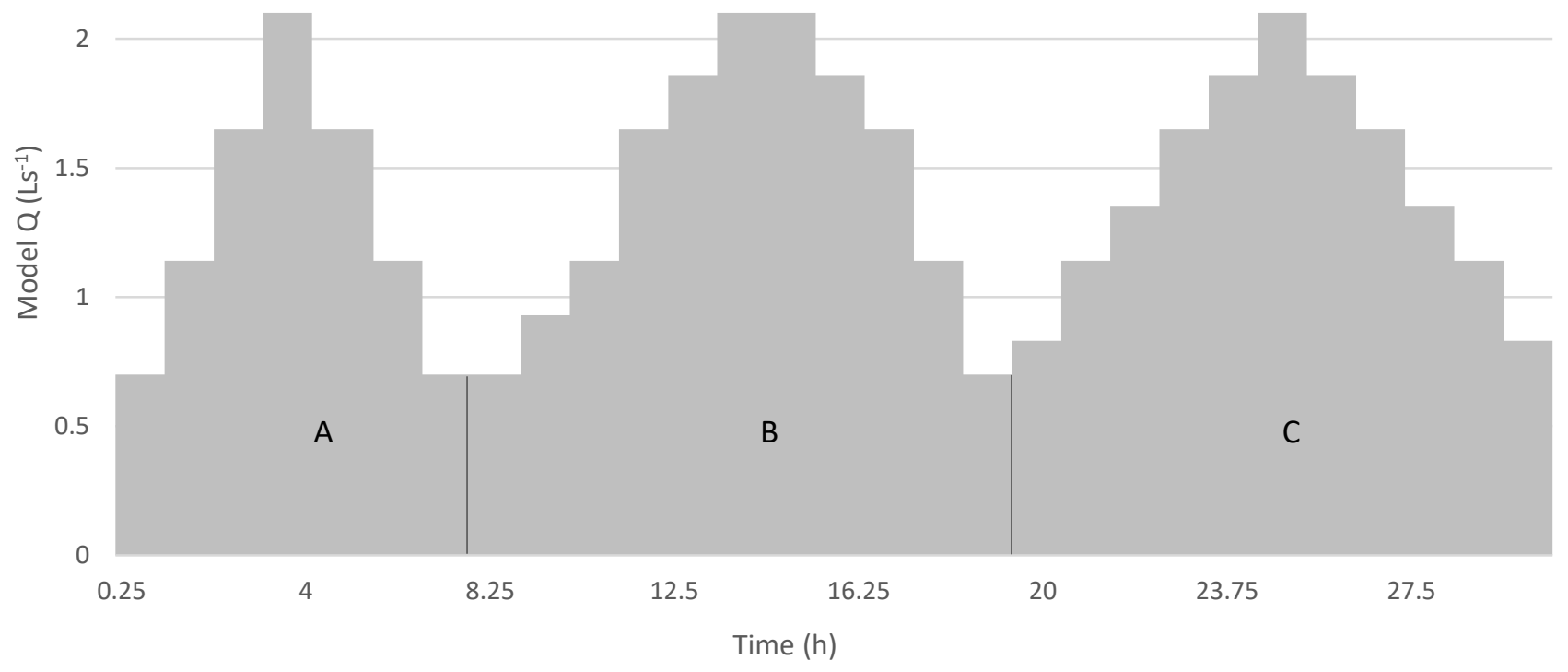




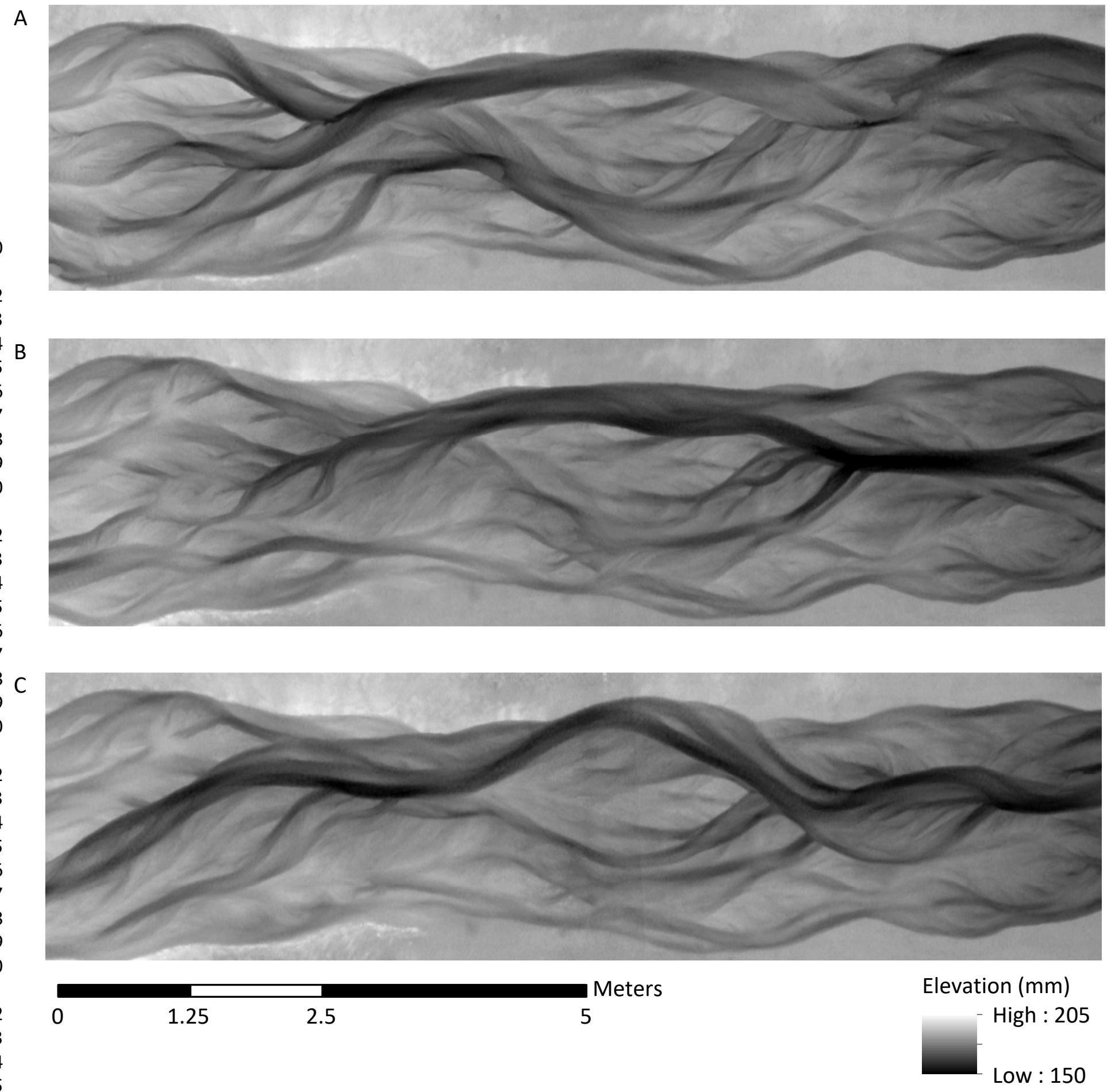




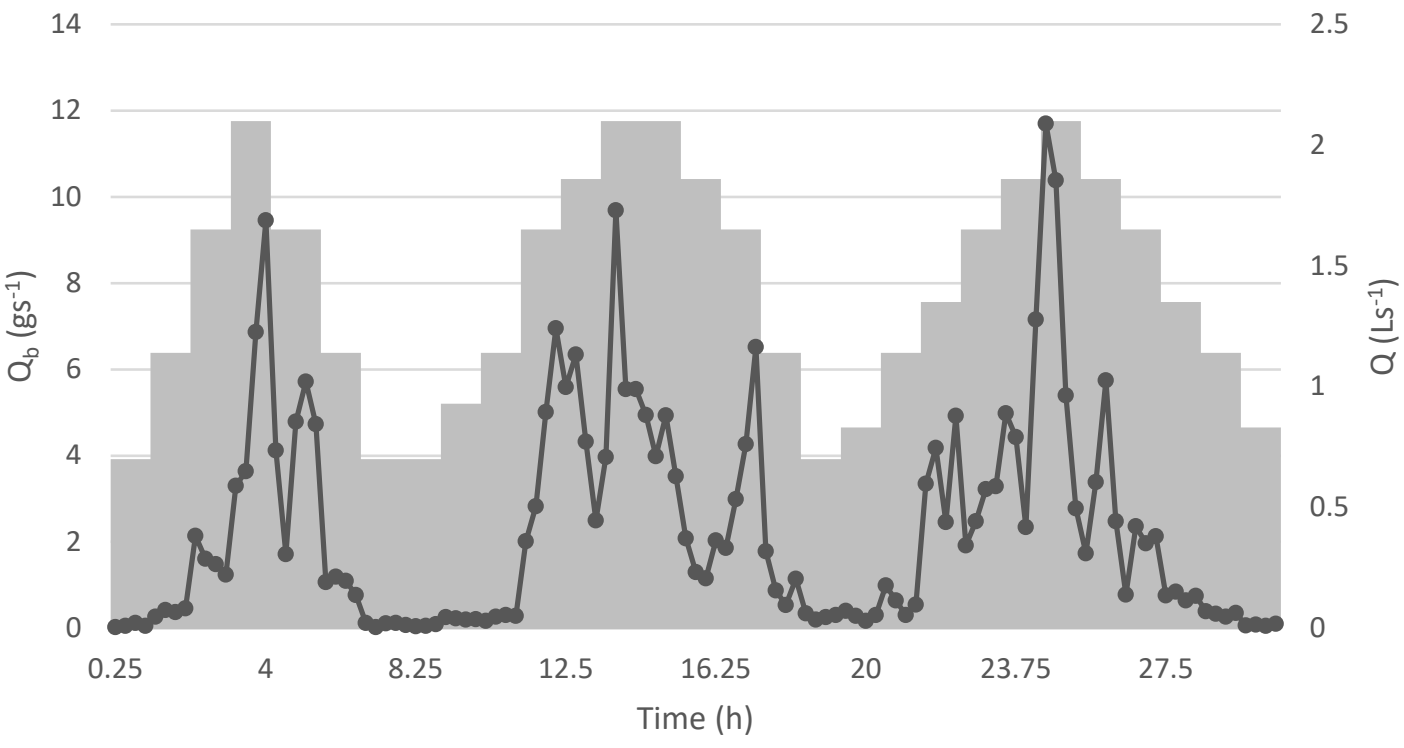

b) 100

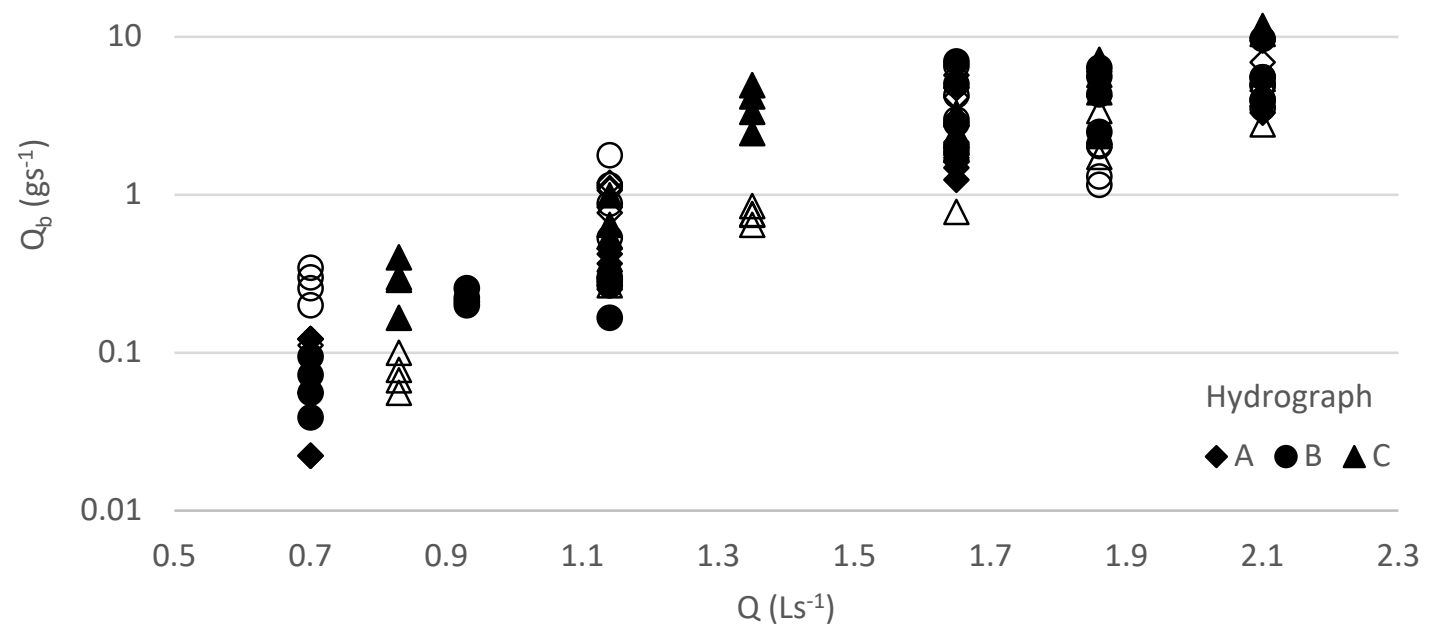

http://mc.manuscriptcentral.com/esp 


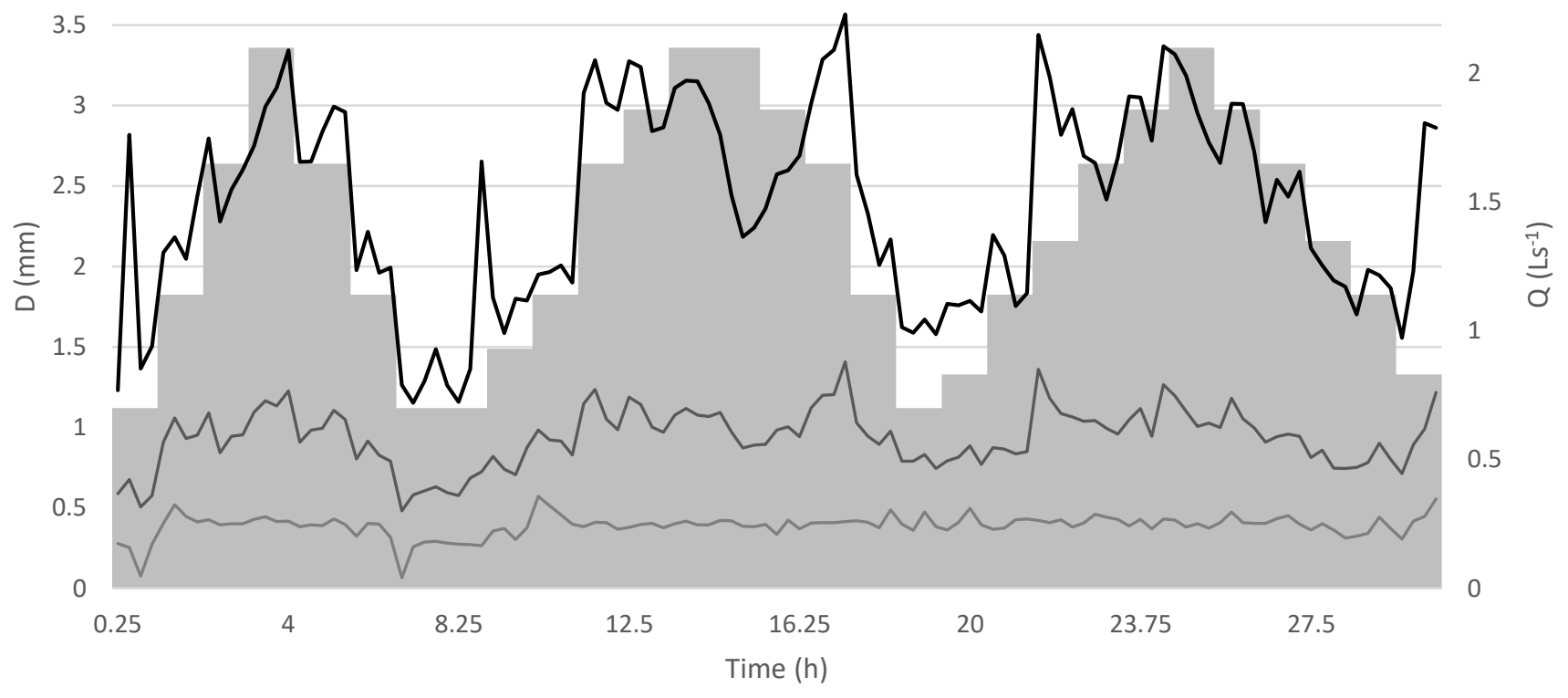

$\mathrm{Q}=\mathrm{D}_{10}-\mathrm{D}_{50}-\mathrm{D}_{90}$ 
a)

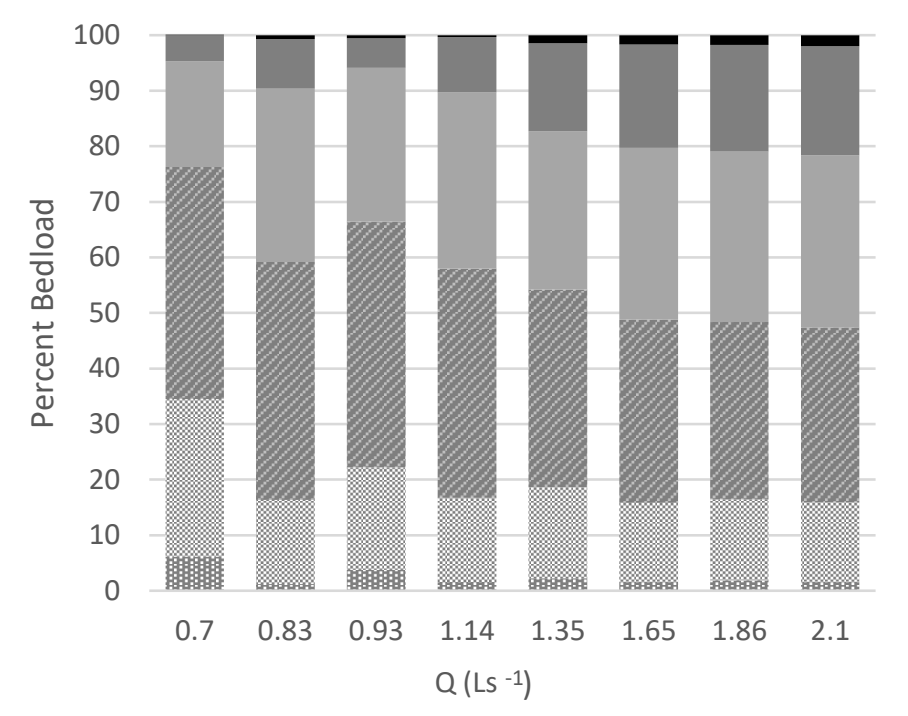

D (mm)

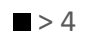

- $2-3.9$

- $1-1.9$

- $0.5-0.9$

$0.25-0.4$

罪< 0.25

15

16

17

18

b)
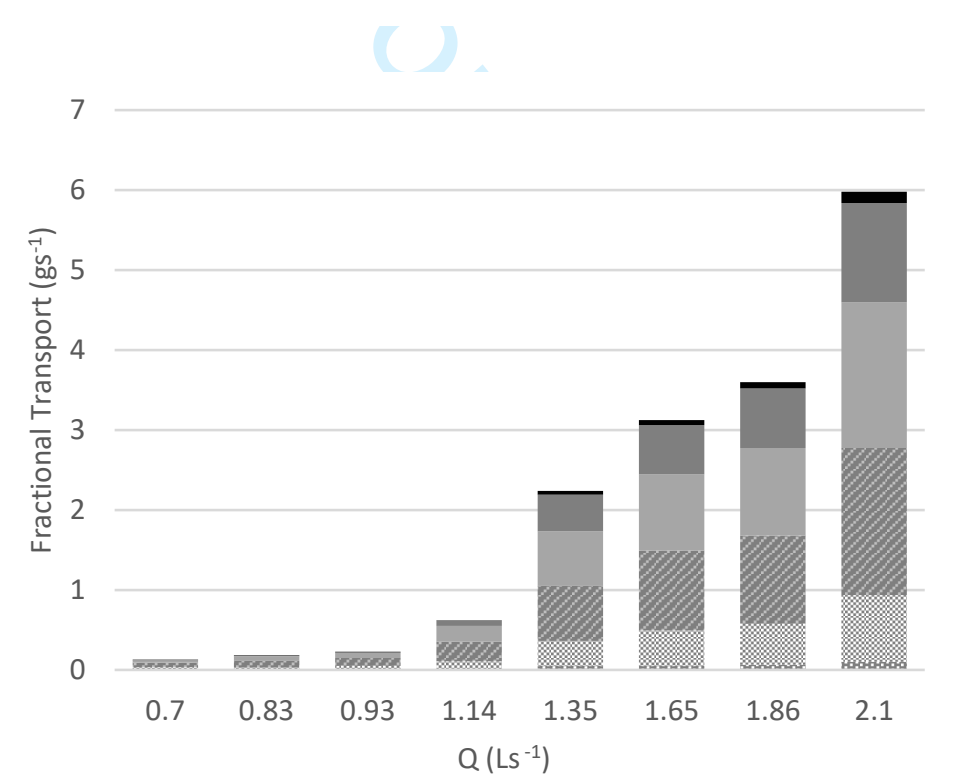

$\mathrm{D}(\mathrm{mm})$

- $>4$

- 2 - 3.9

ㅁ 1 - 1.9

a $0.5-0.9$

$0.25-0.4$

朋 $<0.25$

Subsurface 


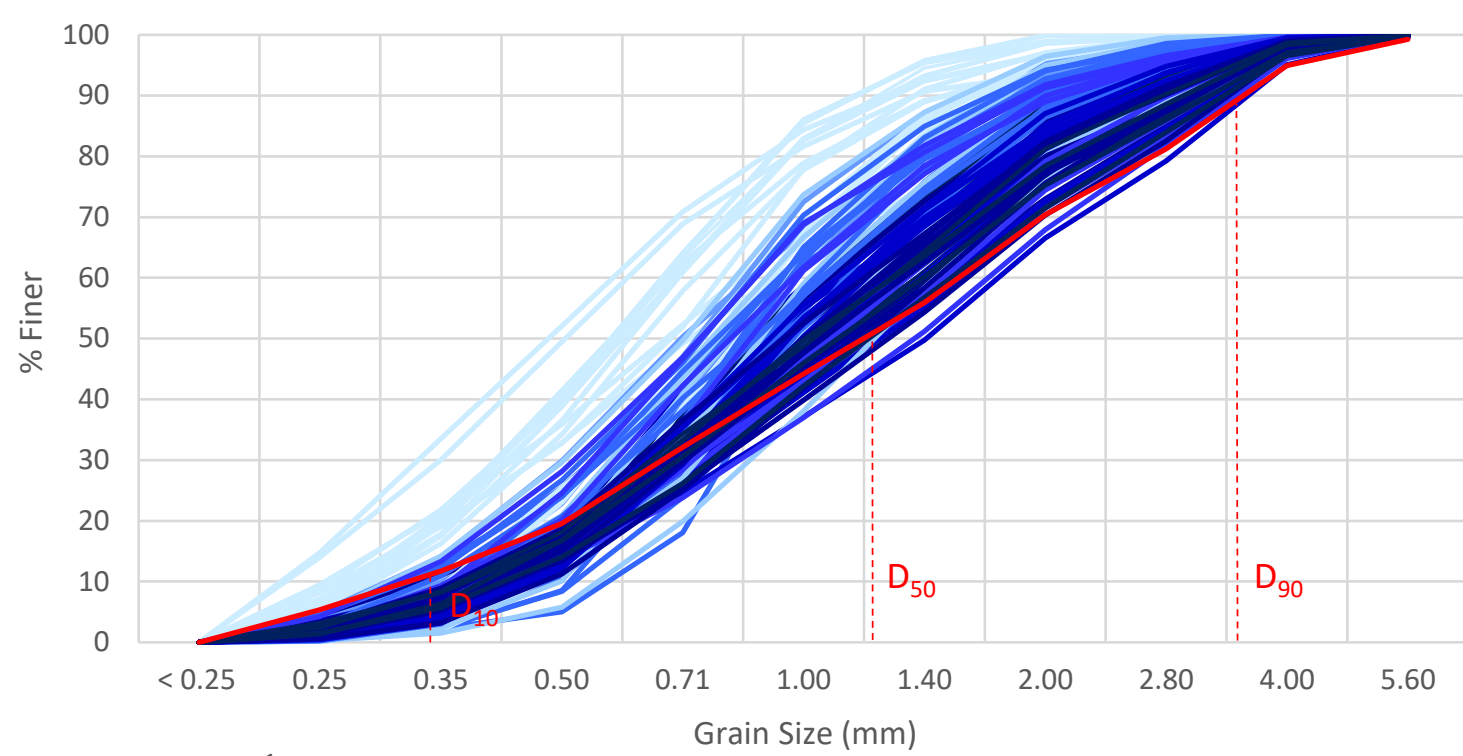

Discharge $\left(\mathrm{Ls}^{-1}\right)$
0.7 


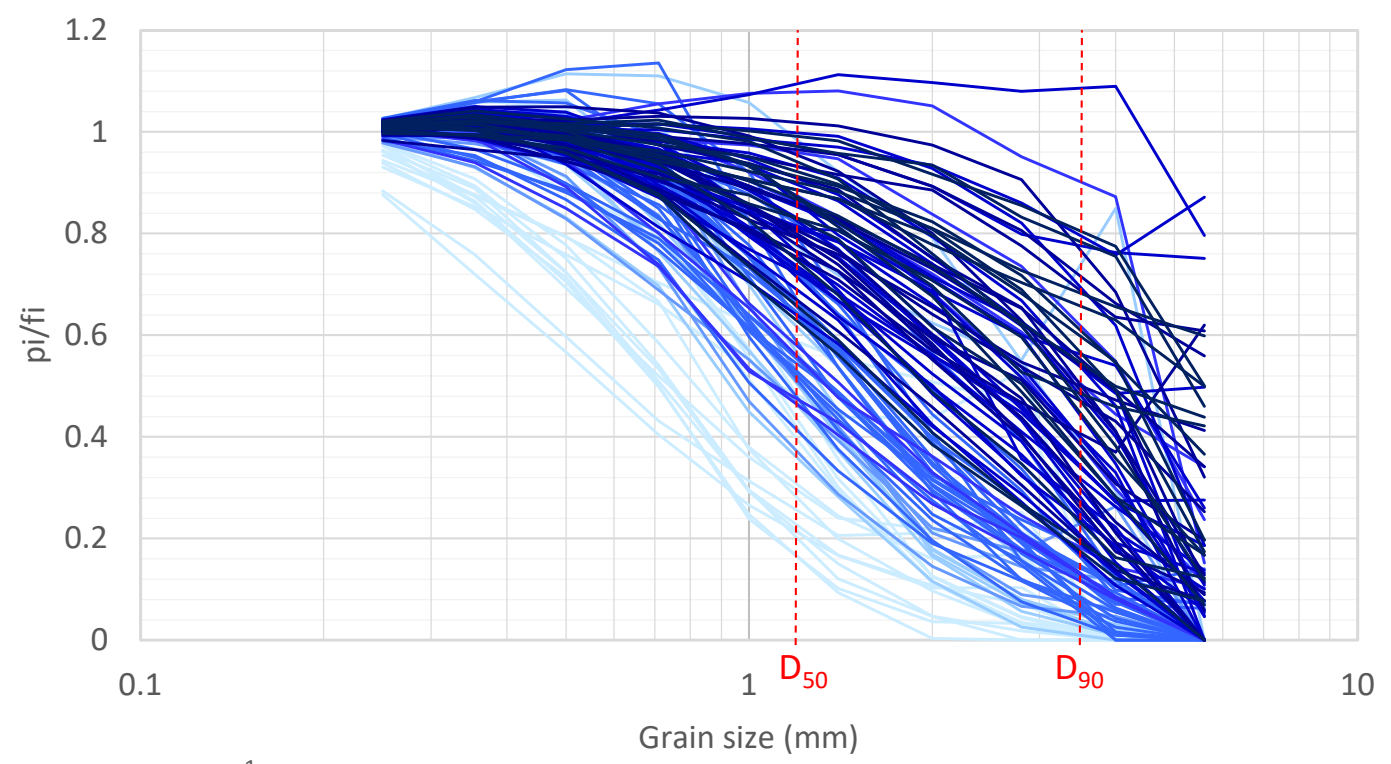

Discharge $\left(\mathrm{Ls}^{-1}\right)$

\begin{tabular}{l|l|l|l|l|l|l|l|}
\hline 0.7 & 0.83 & 0.93 & 1.14 & 1.35 & 1.65 & 1.86 & 2.1 \\
\hline
\end{tabular}


a)

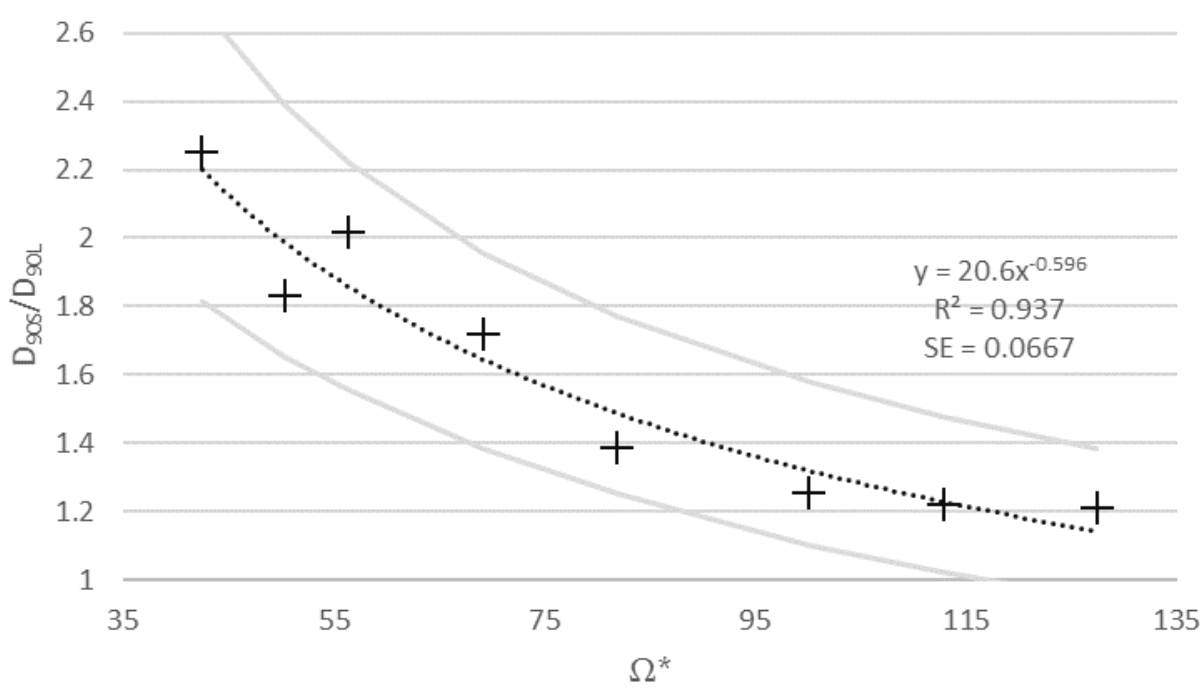

b)

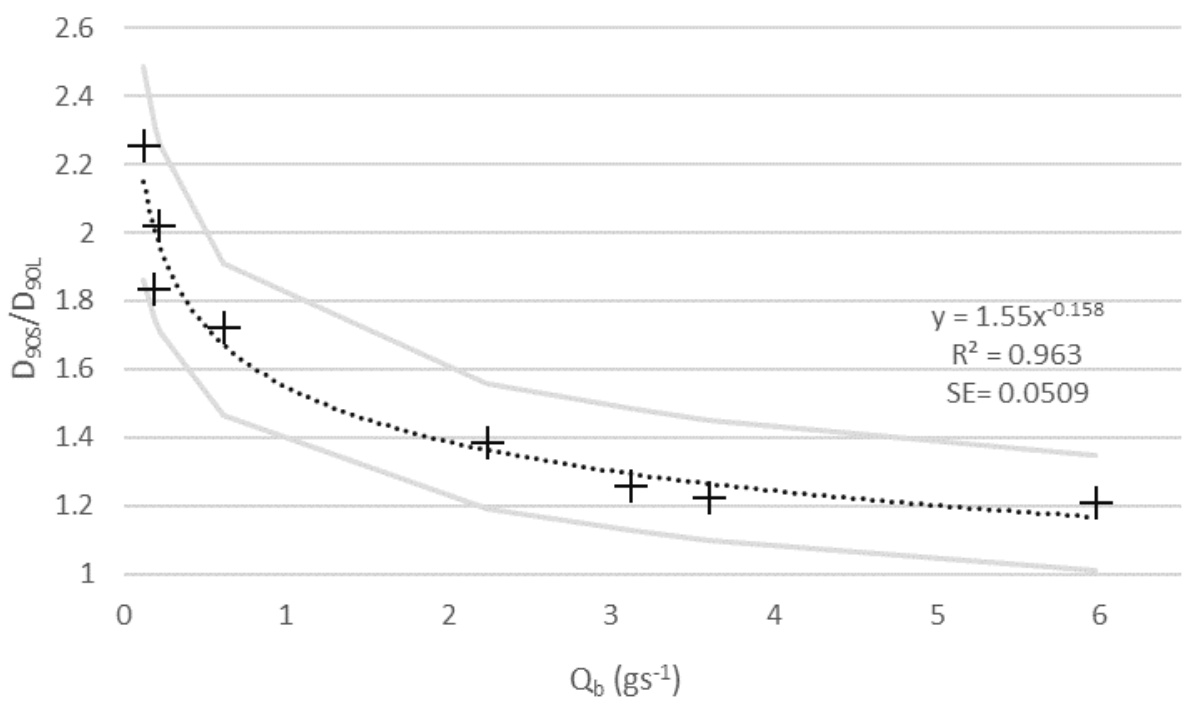

http://mc.manuscriptcentral.com/esp 


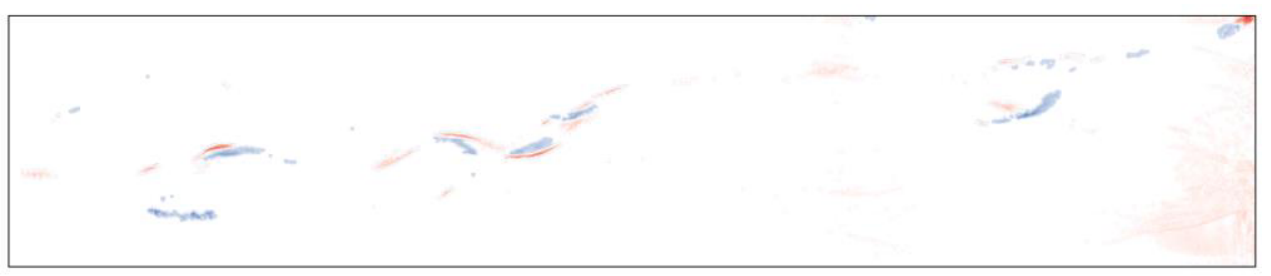

$Q=1.14 L^{-1}$

$t=2 h$

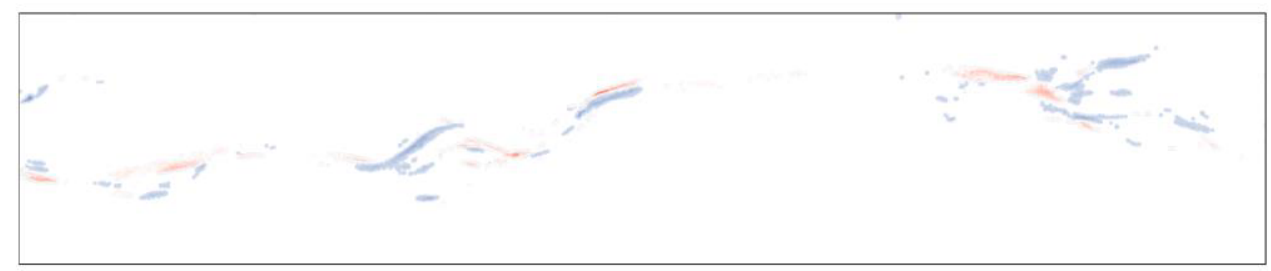

$Q=1.65 \mathrm{Ls}^{-1}$

$t=3 h$

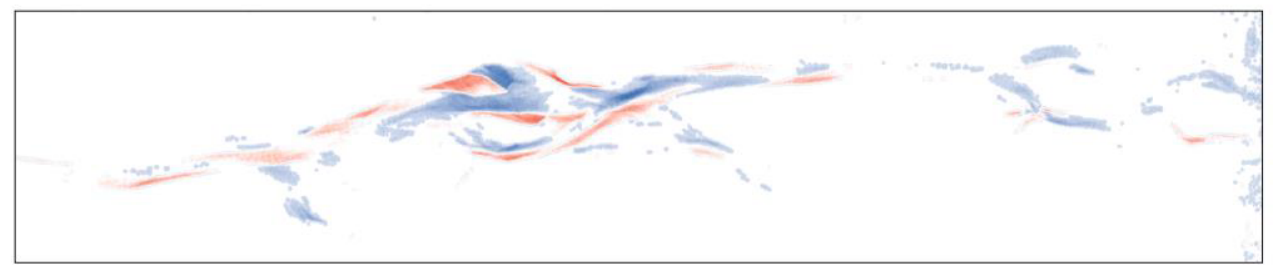

$Q=2.1 \mathrm{Ls}^{-1}$

$t=4 h$

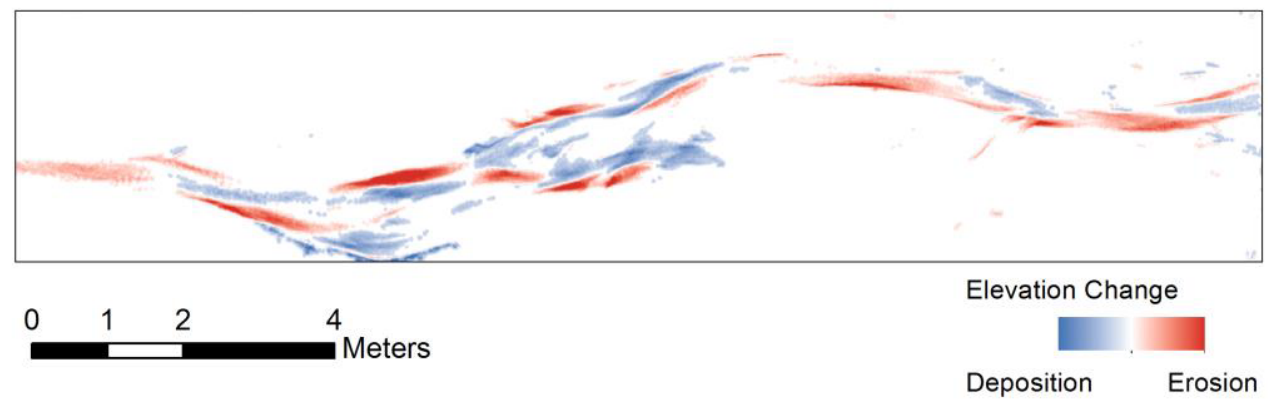


a)

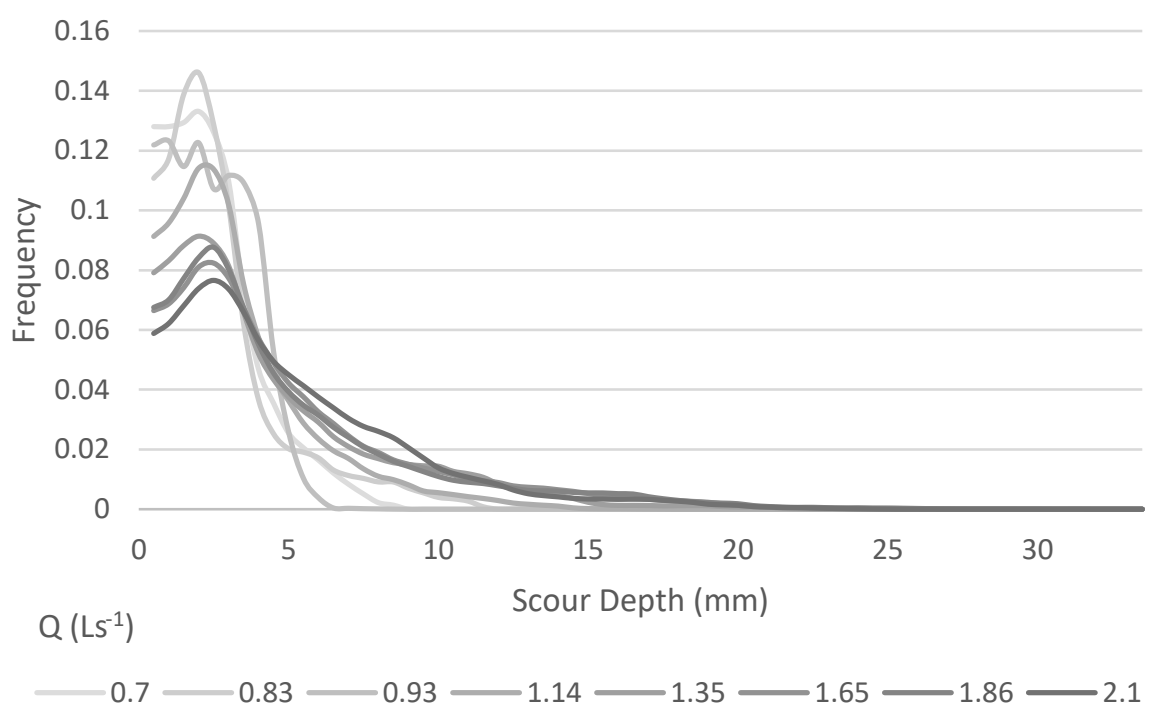

b)

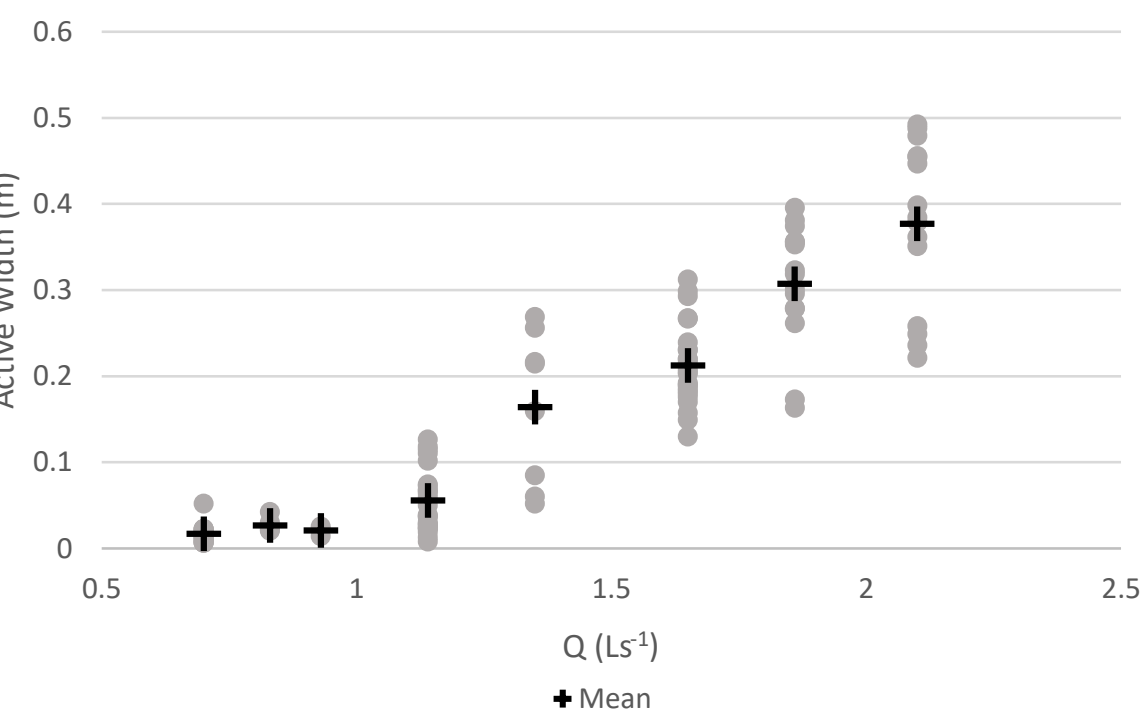

http://mc.manuscriptcentral.com/esp 

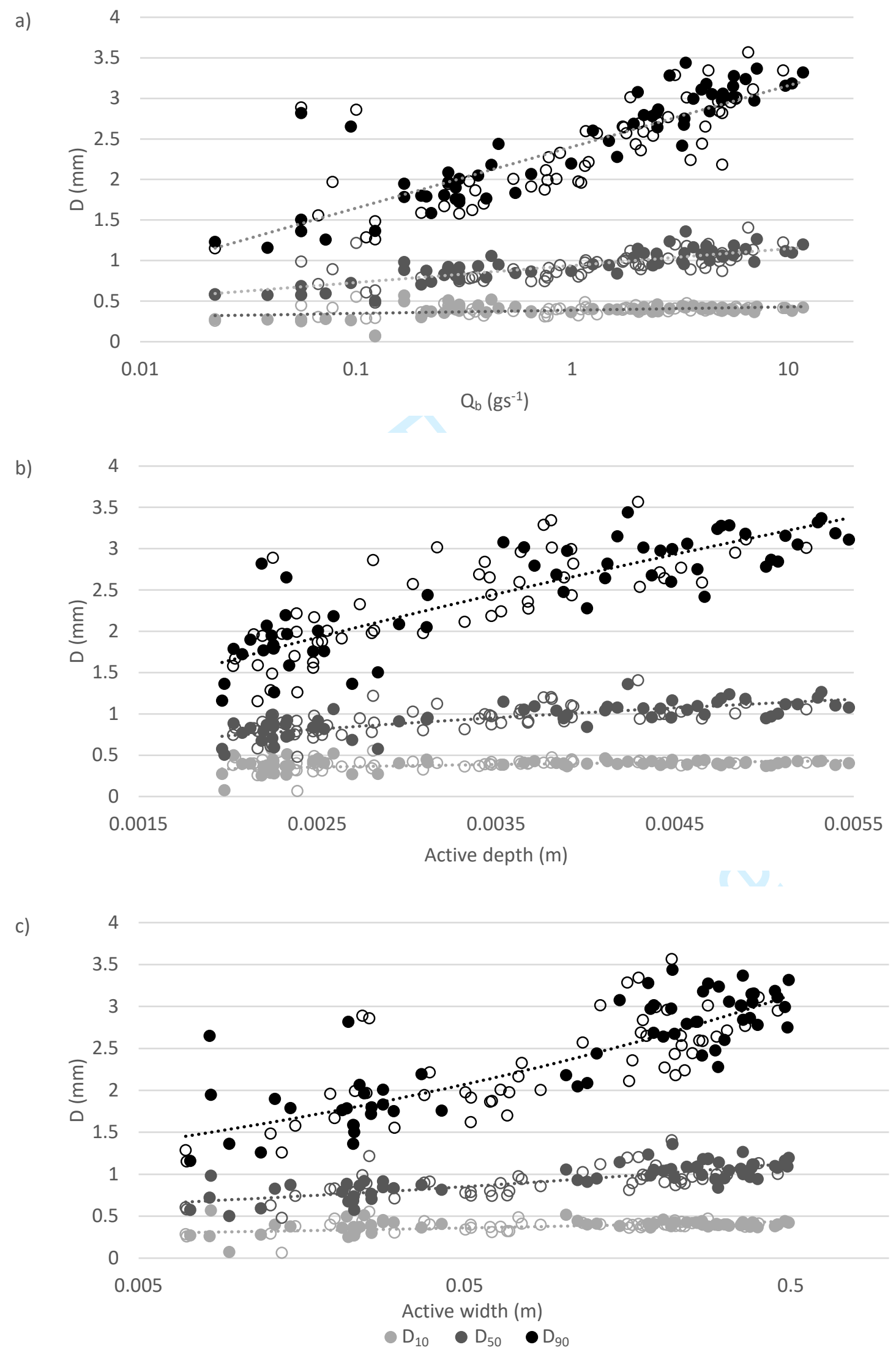

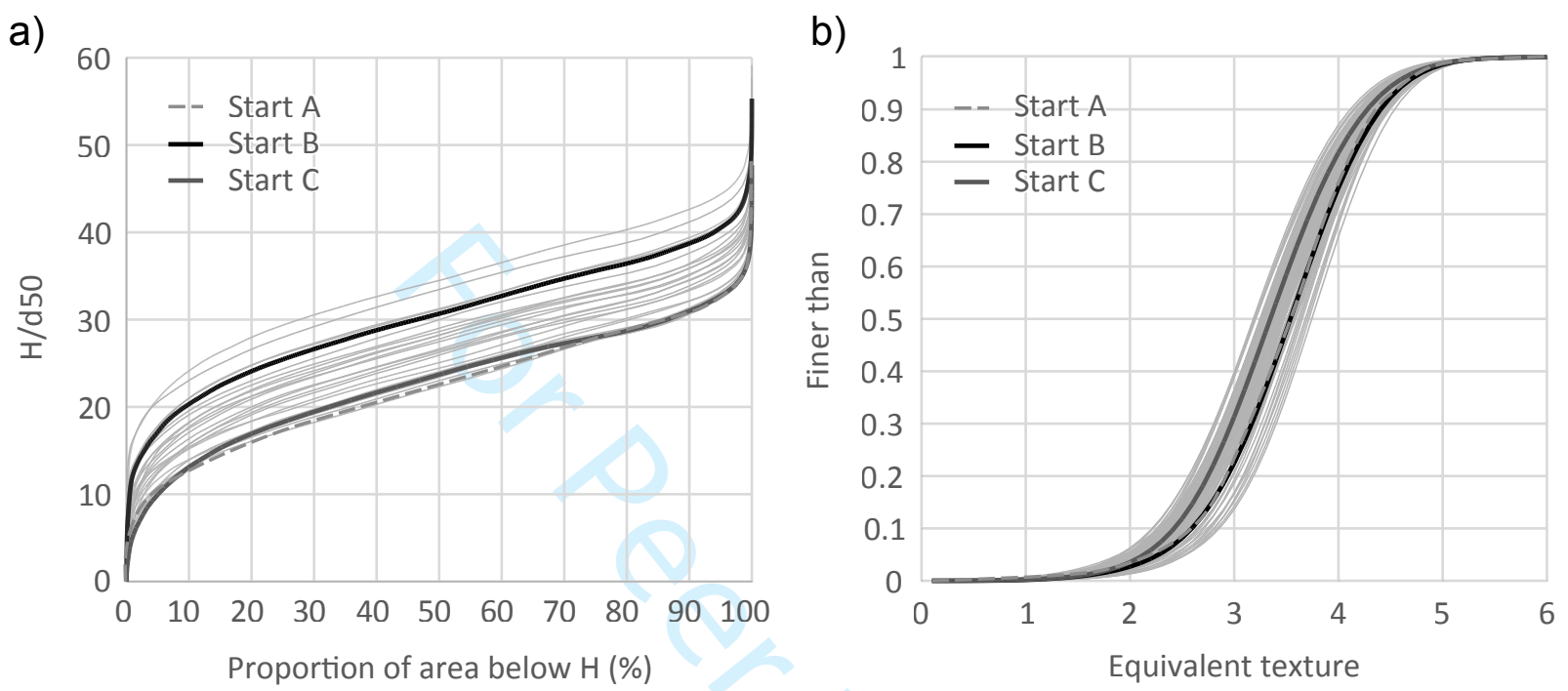
Graphical Information

Title: Evolution of Grain Size Distributions and Bed Mobility during Hydrographs in Gravel-Bed Braided Rivers

Authors: S. Peirce*, P. Ashmore, and P. Leduc

Key findings: Investigation in a physical model of gravel-bed braided river indicated that bed mobility transitioned from partial mobility to selective mobility at discharges $\sim 50 \%$ of peak discharge, and approached equal mobility at the highest (i.e., diurnal peak/channel-forming) discharges. The threshold between partial mobility and selective mobility coincided with a threshold for detectable morphological change and substantial increases in bedload transport rates.

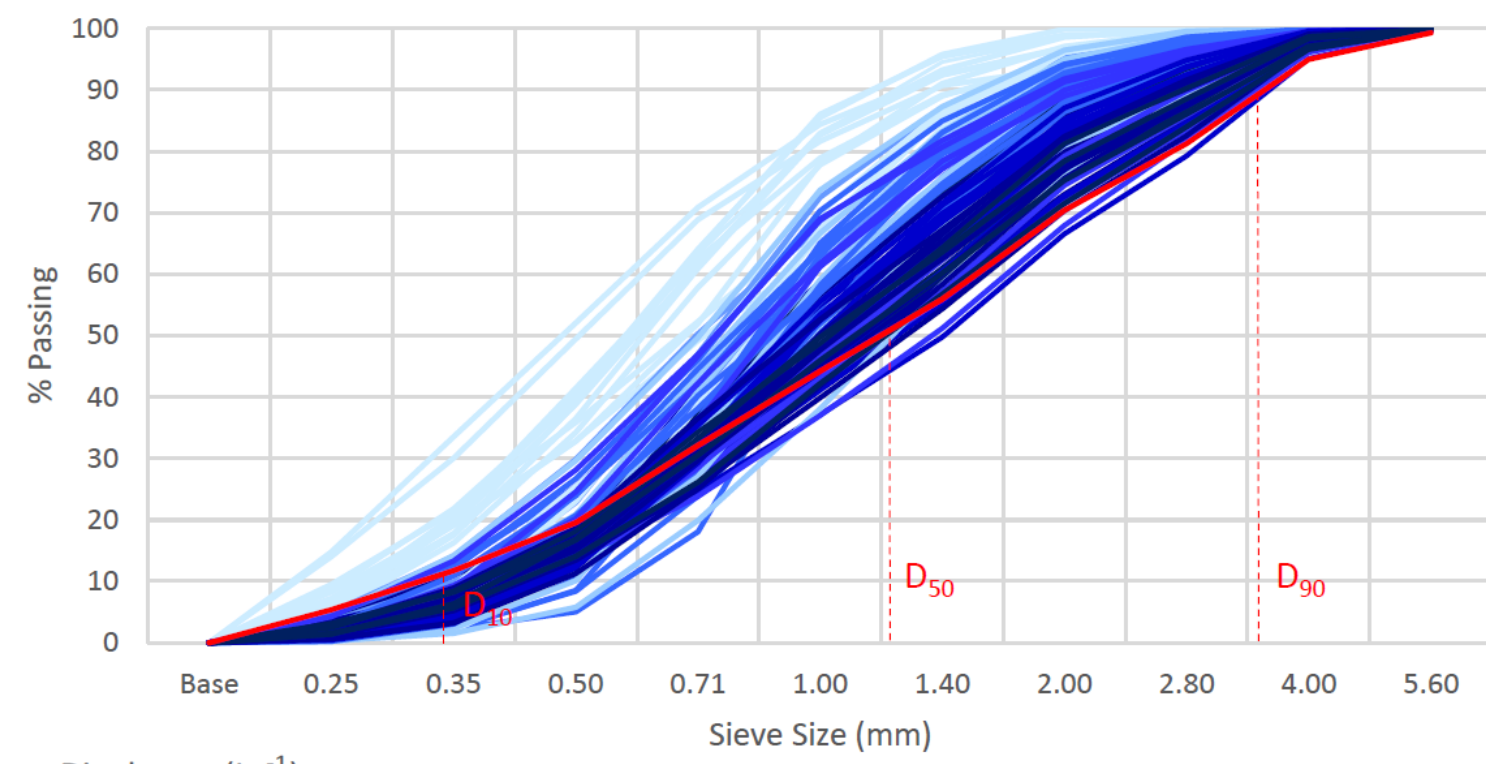

Discharge $\left(\mathrm{Ls}^{-1}\right)$
0.7
0.83
0.93
1.14
1.35
1.65
1.86
2.1 